\title{
RESTITUTION AND THE RESCUE OF LIFE
}

\section{MITCHELL McINNES•}

The author argues that restitutionary relief should be available to life rescuers. Analyzed in terms of the Canadian principle of unjust enrichment, it can be said that $a$ victim receives an enrichment and $a$ rescuer suffers a corresponding deprivation when there is no juristic reason for the enrichment. Policy considerations and precedent also favour the recognition of a right of recovery in limited circumstances. A rescuer's measure of relief should generally be restricted to reimbursement of his expenses, though a professional should also be entitled to remuneration for his services. Policy considerations militate against the availability of privately financed rewards, and against compensation for losses and injuries.
L'auteur soutient qu'une indemnisation aux fins de restitution devrait être accordée aux personnes qui effectuent des sauvetages. Analysé en regard du principe canadien d'enrichissement sans cause, on peut avancer qu'une victime bénéficie d'un enrichissement et qu'un sauveteur souffre d'une privation correspondante quand l'enrichissement est sans cause juridique. Les précédents et certaines considérations de principe favorisent également la reconnaissance d'un droit de recouvrement dans des circonstances limitées. L'indemnisation devrait généralement se limiter au remboursement des dépenses engagées par le sauveteur, encore qu'un spécialiste devrait également avoir le droit d'être rémunéré pour ses services. Des considérations de principe militent contre la distribution de récompenses financées par le secteur privé et contre les dommages-intérêts pour pertes et blessures.

\section{TABLE OF CONTENTS}

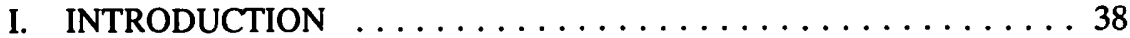

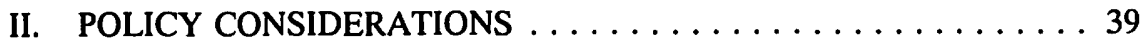

A. POLICY ARGUMENTS FOR DENYING RECOVERY . . . . 39

B. POLICY ARGUMENTS FOR ALLOWING RECOVERY . . . . 44

III. RELIEF FOR NECESSITOUS INTERVENORS $\ldots \ldots \ldots \ldots \ldots 46$

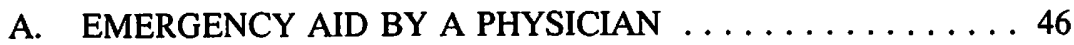

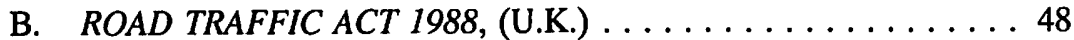

C. THE SUPPLY OF NECESSARIES $\ldots \ldots \ldots \ldots \ldots \ldots \ldots 48$

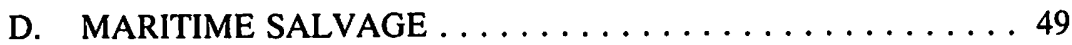

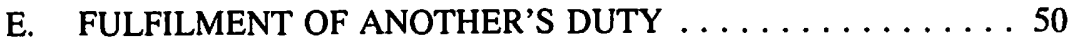

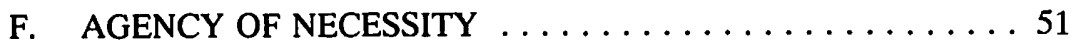

IV. CONDITIONS FOR RECOVERY BY LIFE RESCUERS $\ldots \ldots \ldots 53$

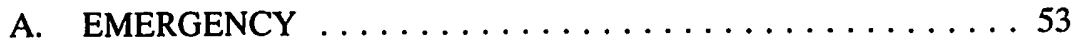

B. OFFICIOUSNESS AND APPROPRIATENESS

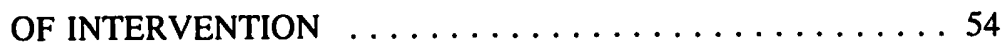

C. APPROPRIATE INTENTION IN INTERVENING . . . . . 59

D. REASONABLENESS OF ACTIONS $\ldots \ldots \ldots \ldots \ldots \ldots \ldots 6$

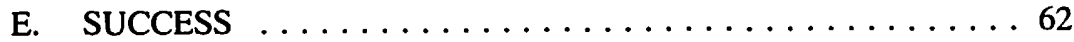

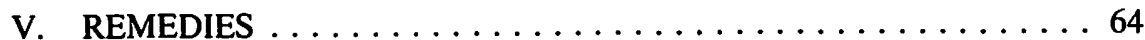

B.A., LL.B. (Alberta), LL.M., Ph.D. (Cambridge), Law Clerk, Supreme Court of Canada.

This paper is based on a chapter of a doctoral dissertation written at Trinity Hall, Cambridge University. I would like to thank my supervisor, Mr. Andrew Tettenborn, and Ms. Alison Hughes for their helpful comments. Funding was provided by the Social Sciences and Humanities Research Council of Canada. 


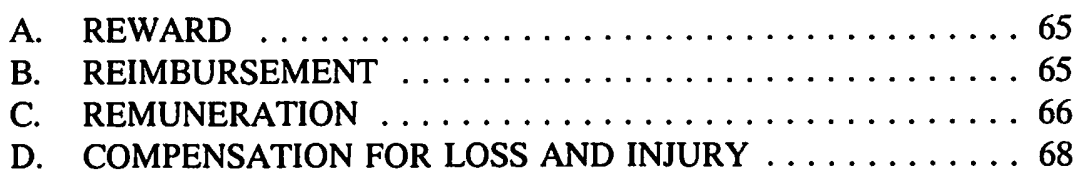

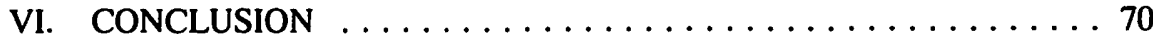

\section{INTRODUCTION}

The law's position regarding rescuers of human life' has changed considerably in the past century. While a general duty to rescue has yet to be recognized, an obligation exists in a growing number of situations. ${ }^{2}$ Similarly, the Samaritan will now be compensated if injured while responding to a negligently created peril. ${ }^{3}$ If he inflicts a loss during intervention, he will often be protected from both criminal and civil liability. ${ }^{4}$ Significantly, however, he remains generally unable to claim restitutionary relief. ${ }^{5}$ The English life rescuer has yet to receive reimbursement for his expenses or remuneration for his efforts, and but for one remarkable case, ${ }^{6}$ the same can be said of the Canadian rescuer. ${ }^{7}$ The aim of this article is to examine the reasons for that situation, and to explore the possibility of reform in Anglo-Canadian law. It will be argued that recovery should be available, though carefully confined.

The ensuing discussion will be separated into four parts. First, policy arguments for and against recovery will be evaluated. Second, situations in which necessitous intervenors are already granted some form of relief will be examined with a view to ascertaining possible conditions and limitations to a right of recovery for life rescuers. Third, those conditions

1 Unless otherwise indicated, the term "rescuer" will refer to one who provides emergency assistance for the preservation of human life or health on land. As will be explained below, the law has long treated maritime salvors differently. For the sake of convenience, a person in need of rescue will be referred to as "victim," even though the provision of assistance may spare him any actual harm. Finally, the term "life rescue" is also used for the sake of convenience; it should generally be taken to include services which prevent any physical harm.

M. McInnes, "The Question of a Duty to Rescue in Canadian Tort Law" (1990) 25 Dalhousie L.J. 85 [hereinafter "Duty"]; L.N. Klar, Tort Law (Toronto: Carswell, 1991) c. 6.

Liability may be imposed on a person who negligently imperils himself (Batky v. C.N.R. (1977), 18 O.R. (2d) 481 (Co. Cl.); Baker v. T.E. Hopkins \& Son Ltd., [1958] 3 All E.R. 147 at 153; aff'd. [1959] 3 All E.R. 225; Harrison v. British Railways Bd., [1981] 3 All E.R. 679), or another person: Haynes v. Harwood, [1935] 1 K.B. 146; Videan v. Br. Tpt. Comm., [1963] 2 Q.B. 650 (C.A.); Horsley v. McLaren, [1972] S.C.R. 441.

4 M. Mclnnes, "Good Samaritan Statutes: A Summary and Analysis" (1992) 26 U.B.C. L. Rev. 239; M. Mclnnes, "Protecting the Good Samaritan: Defences for the Rescuer in Anglo-Canadian Criminal Law" (1994) Crim. Law Q. (forthcoming); L. Wilson, "The Defence of Others - Criminal Law and the Good Samaritan" (1988) 33 McGill L.J. 756.

$5 \quad$ G. Jones, Restitution in Private and Public Law (Bombay; London: Tripathy; Sweet \& Maxwell, 1991) at 155.

" Matheson v. Smiley, [1932] 2 D.L.R. 787 (Man. C.A.); cf. Soldiers Memorial Hospital v. Sanford, [1934] 2 D.L.R. 334, 7 M.P.R. 334 (N.S.S.C.); Hastings v. Semans Village, [1946] 4 D.L.R. 695, [1946] 3 W.W.R. 449 (Sask. C.A.).

7 "Canada" refers to the country's common law provinces and territories. In Quebec, relief is available on the basis of the Roman law concept of negotiorum gestio, infra note 53. 
and limitations will be analyzed in detail. Finally, consideration will be given to the different measures of relief that could be made available. ${ }^{8}$

By way of preface, it can be noted that a rescuer's claim for relief may be more likely to (soon) succeed in Canada than in England. Canadian law long ago adopted the principle of unjust enrichment," which in essence "prevent[s] a man from retaining the money of or some benefit derived from another which it is against conscience that he should keep." ${ }^{10}$ While a precise theoretical explanation of the Canadian position has yet to emerge conclusively, ${ }^{11}$ the criteria of the principle are well established ${ }^{12}$ and clearly the possibility of recovery by a Good Samaritan would be given consideration. In contrast, English courts have traditionally been more circumspect and have only recently recognized an independent law of restitution based upon the principle of unjust enrichment. ${ }^{13}$ Consequently, they might be less enthusiastic about accommodating a rescuer's claim.

\section{POLICY CONSIDERATIONS}

\section{A. POLICY ARGUMENTS FOR DENYING RECOVERY}

The law's traditional reluctance to grant relief to necessitous intervenors was partially attributable to considerations that are today of historical relevance only. For example, recognition of a right of recovery was previously inhibited by the requirements of the ancient forms of actions. ${ }^{14}$ Similarly, the now discredited ${ }^{15}$ "implied contract" theory

There are four possibilities. Rescuers could be permitted: (i) reimbursement for the value of the expenses they incur; (ii) remuneration for the value of the services they render; (iii) rewards which exceed reimbursement or remuneration; or (iv) compensation for losses or injuries sustained in the course of intervention.

Morrison v. Canadian Surety Co., [1954] 4 D.L.R. 736 (Man. C.A.); Deglman v. Guaranty Trust Co. of Canada, [1954] S.C.R. 725; County of Carleton v. City of Ottawa, [1965] S.C.R. 663; Pettkus v. Becker, $[1980] 2$ S.C.R. 834.

Fibrosa Spolka Akcyjna v. Fairbairn Lawson Combe Barbour Ltd., [1943] A.C. 32 at 61, Lord Wright. See also American Law Institute, Restatement of the Law of Restitution: Quasi-Contract \& Constructive Trusts (St. Paul, Minn: American Law Institute Publishers, 1937) at 11 [hereinafter Restatement].

Two possibilities exist. First, unjust enrichment may constitute a general principle which (i) provides an analytical framework within which established instances of restitutionary relief may be understood, refined and organized; and (ii) guides analysis in cases in which new claim types are pursued. Alternatively, unjust enrichment may serve as a cause of action in itself. It probably matters little in practice which view is adopted: P.D. Maddaugh \& J.D McCamus, The Law of Restitution (Aurora, Ont.: Canada Law Book, 1990) at 21-27.

12 See e.g. Rathwell v. Rathwell, [1978] 2 S.C.R. 436 at 455, Dickson J.:

[For] the principle to succeed, the facts must display an enrichment, a corresponding deprivation, and the absence of any juristic reason - such as a contract or disposition of law - for the enrichment.

Lipkin Gorman v. Karpnale Ltd., [1991] 2 A.C. 548, 558 (Lord Bridge), 559 (Lord Templeman), 568 (Lord Ackner), 572, 577.578 (Lord Goff); cf. Woolwich Building Society v. I.R.C., [1992] 3 W.L.R. 366 at 414, Lord Browne-Wilkinson.

Such a development has been favoured by leading scholars: see Lord Goff \& G. Jones, The Law of Restitution, 3d ed. (London: Sweet \& Maxwell, 1986) at 15-16; cf. P. Birks, An Introduction to the Law of Restimtion (Oxford: Clarendon Press, 1985) at 16-25. 
of restitution, ${ }^{16}$ with its emphasis on the existence or imputation of a request, did not readily accommodate claims of individuals who acted on the basis of altruistic impulses. Finally, given the law's traditional fixation on contractual notions of liability, the courts may have been influenced by the dramatic failure of Lord Mansfield's suggestion ${ }^{17}$ that a moral obligation ought to be sufficient consideration for a promise to pay. ${ }^{18}$

Of course, arguments do not always become attenuated over time. The famous dictum of Bowen L.J. in Falcke v. Scottish Imperial Ins. Co. ${ }^{19}$ is illustrative: "Liabilities are not to be forced upon people behind their backs any more than you can confer a benefit upon a man against his will." 20

Expressly or by implication, that quotation raises a number of issues and considerations; some are now of little importance, but others remain relevant. As to the former, it can be noted that Bowen L.J.'s opinion was a product of the individualistic ethos that prevailed in $1886 .{ }^{21}$ To the extent that societal attitudes have changed in the past century, legal reform may be in order.

Lipkin Gorman v. Karpnale Lid., supra note 13; cf. Guinness plc v. Saunders, [1990] 2 A.C. 663 at 689, 692, 693, Lord Templeman.

See generally, P. Birks \& J.G. McLeod, "The Implied Contract Theory of Quasi-Contract: Civilian Opinion Current in the Century Before Blackstone" (1989) 6 Oxford J. of Legal Studies 46.

See e.g. Hawkes v. Saunders (1782), 1 Cowp. 289.

See e.g. Eastwood v. Kenyon (1840), 11 A. \& E. 438. Consequently, Anglo-Canadian rescuers would find it difficult to enforce a promise of compensation made after the provision of services. Interestingly, however, such promises have been enforced in American law: Webb v. McGowin, 27 Ala. Civ. App. 82, 168 So. 196 (1935), cert. denied 168 So. 199; contra Harrington v. Taylor, 225 N.C. 690, 36 S.E. 2d 277 (1945); cf. Medberry v. Olcovich, 15 Cal. App. 2d 263, 59 P. 2d 551 (1936); Mills v. Wyman, 3 Pick. (20 Mass.) 207 (1825).

(1886) 34 Ch. D. 234 at 248 (C.A.) [hereinafter Falcke]. Though often cited in opposition to the availability of restitutionary relief for necessitous intervenors, Falcke did not involve the provision of emergency assistance. E had mortgaged an insurance policy to F. Owing to the fraud of a third party, E erroneously believed that he had bought F's interest, and subsequently made several large payments on the policy to keep it alive. The security was realized, but was insufficient to discharge the debt owed on the mortgage. E claimed that he should be indemnified for his payments in priority to F. The court rejected E's position. Cotton L.J. noting (34 Ch. D. at 243) that:

It would be strange indeed if a mortgagor spending money on the mortgaged property could establish a charge in respect of that expenditure in priority to the mortgage.

The influence of the decision also seems exaggerated insofar as $E$ had sought a lien on the property in question. As established in Nicholson v. Chapman (1793), 2 H.Bl. 254; cf. Robinson v. Walter (1616) 3 Bulst. 269, there are great dangers in granting proprietary relief in all but exceptional circumstances. (The claim of a life rescuer would be for in personam relief.) On the other hand, it is not the ratio of Falcke, but rather the policy considerations in Bowen L.J.'s dictum, that may be relevant.

The same sentiment is captured in Pollock C.B.'s equally pithy statement, "One cleans another's shoes; what can the other do but put them on?"; Taylor v. Laird (1856), 25 L.J. Ex. 329 at 332, 156 E.R. 1203.

Speaking of that era, E.W. Hope ("Officiousness" (1929-30) 15 Cornell L.Q. 25 at 29) observed that:

Self direction or personal autonomy is a mark of the English race. The

Englishman, as opposed to one of Latin lineage, does not easily coalesce with the mass. He distinctly wishes to live his own life, make his own contacts, or as he frequently says, "muddle through" in his own way. 
Nevertheless, much in Bowen L.J.'s judgment continues to demand consideration. In particular, the courts properly remain vigilant to discourage officiousness ${ }^{22}$ and to protect the individual's ability to control his own purse strings. It would be contrary to public policy to encourage meddlers to foist their services when they are unwanted, unnecessary and unjustified. ${ }^{23}$ Similarly, it would be undesirable if the law was quick to forcibly reallocate the wealth of people who receive unrequested services. ${ }^{24}$ As will be discussed later, however, both of those concerns can be guarded against in the rescue context without the need to entirely deny relief. The circumstances of an emergency will often ensure that an intervenor's actions are not officious. Moreover, there are limited circumstances in which the law will impose restitutionary liability on one who neither freely accepts ${ }^{25}$ nor requests ${ }^{26}$ a benefit, but who receives an incontrovertible benefit. ${ }^{27}$

"Officiousness" has been defined as "interference in the affairs of others not justified by the circumstances under which the interference takes place.... [W]here a person has officiously conferred a benefit upon another, the other is enriched but is not considered to be unjustly enriched.": Restatement, supra note 10 at $\$ 2$. See also Goff \& Jones, supra note 13 at $42-44$.

The dictum is Falcke has too often been extended beyond its proper boundaries. Restitution should generally be denied if a plaintiff "forced" a benefit on a defendant "behind [his] back" or "against his will." But there is a difference between conferring a benefit against the wishes of a person, and conferring a benefit which has not been requested, but which would be welcome. Moreover, succour can be considered to have been "forced" upon a victim not by a rescuer, but rather by circumstance: Birks, supra note 13 at 195.

P. Matthews, "Freedom, Unrequested Benefits and Lord Denning" (1981) 40 Camb. L.J. 340; Leigh v. Dickeson (1884), 15 Q.B.D. 60 (C.A.).

"Free acceptance" occurs when a person accepts a benefit, knowing that it was not offered gratuitously and has the opportunity to reject it: Goff \& Jones, supra note 13 at 18-19; Jones, supra note 5 at 108; Birks, supra note 13 at 114-116; cf. A. Burrows, The Law of Restitution (London: Butterworths, 1993) at 11-14, 315-320; M. Garner, "The Role of Subjective Benefit in the Law of Unjust Enrichment" (1990) 10 O.J.L.S. 42; G. Mead, "Free Acceptance: Some Further Considerations" (1989) 105 L.Q.R. 460.

There are difficulties in applying the doctrine of free acceptance to a situation involving the provision of emergency assistance. As a test of enrichment, it establishes unconscientious behaviour which debars a recipient from "subjectively devaluing" the services provided: P. Birks, "In Defence of Free Acceptance" in A. Burrows, ed. Essays on the Law of Restitution (Oxford: Clarendon Press, 1991) 105 at 128. However, a victim's acceptance of emergency assistance is borne of necessity, rather than unconscientiousness, and practical volition is precluded by circumstance.

It is unlikely that a court would grant restitutionary relief on the basis of a request given that a contract formed in emergency circumstances would probably be refused enforcement: infra note 121 . Restitution may be awarded if a defendant receives a "incontrovertible benefit": Peel (Reg. Mun.) v. Canada; Peel (Reg. Mun.) v. Ontario, [1992] 3 S.C.R. 762. In the view of Goff \& Jones, that will be the case if he has "gained a financial benefit readily realisable, without detriment to himself, or has been saved an inevitable expense": supra note 13 at 144 . Similarly, Birks argues that a benefit will be incontrovertible if it represents an anticipation of a necessary expenditure, or if it has been realized in money: supra note 13 at 116-124. The various formulations of the incontrovertible benefit concept are fully explored in M. McInnes "Incontrovertible Benefits in the Supreme Court of Canada" (1994) 23 Can. Bus. L.J. 122; M. McInnes, "Incontrovertible Benefits and the Canadian Law of Restitution" (1991) 12 Advocates Q. 323.

It is widely accepted that rescue services constitute an incontrovertible benefit under the "necessary expenditure" branch of the concept: Maddaugh \& Mccamus, supra note 11 at 43 ; Goff \& Jones, supra note 13 at 22; Birks, supra note 13 at 194; Burrows, supra note 25 at 247 . It should not matter that, but for a rescuer's intervention, an expense would not actually have been incurred because a victim would have suffered a threatened harm before being able to arrange for assistance; it ought to be enough that the victim would have incurred the expense if he had been able to do so. 
Such liability may be appropriate when rescue services have been provided.

It might also be argued that a rescuer's claim for relief should be refused because any enrichment enjoyed by a victim will have been voluntarily conferred, ${ }^{28}$ and hence not unjust. Restitution is generally denied to the volunteer..$^{29}$ In response, it can be said that the purported voluntariness of a rescuer's actions should be considered vitiated by circumstances. ${ }^{30}$ Practically speaking, intervention will be the product of moral compulsion, rather than autonomous choice. ${ }^{31}$

It has also been suggested that altruism should be its own reward, ${ }^{32}$ that the gift of life sufficiently enriches both recipient and provider. Certainly, we might think poorly of a rescuer who demanded a huge sum from one to whom he had rendered a simple, though invaluable, service. However, as will be explained more fully below, there is little support for the position that a rescuer generally should be rewarded, remunerated for his services, or compensated for his injuries and losses; instead, the debate primarily turns on the question of whether he should be reimbursed for his expenses. ${ }^{33}$ Seen in that light, the merit of allowing relief appears favourable. It can be strongly argued that one whose life has been saved ought to indemnify his salvor for expenses incurred, as it would be ungrateful and unjust if the beneficiary left the cost of his rescue on the shoulders of his Samaritan.

The fact that a rescuer's measure of recovery would generally be limited to reimbursement also meets two other arguments against the availability of relief. First, it has been suggested that a rule allowing generous awards would entail a moral hazard. If able to financially benefit from intervention, scoundrels might ${ }^{34}$ be tempted to wrongfully create the need for emergency services upon which they could capitalize. ${ }^{35}$ That would

2s Exceptionally, services may be rendered pursuant to a duty: below at Section IV(B)(1).

29 Maddaugh \& McCamus, supra, note 11 at 55; Goff \& Jones, supra note 13 at 30-36.

Birks, supra note 13 at 193-202. Burrows argues that the unjust factor should be based on the "policy-motivated desire of the law to encourage people to intervene": supra note 25 at 242-243, 2122; cf. Birks, supra note 13 at 304-308.

"The impulsive desire to save human life when in peril is one of the most beneficial instincts of humanity...": Scaramanga v. Stamp (1880), 5 C.P.D. 295 at 304, Cockburn C.J. J.P. Dawson, "Negotiorum Gestio: The Altruistic Intermeddler" (1961) 74 Harvard L. Rev. 817 and 1073 at 1125 .

33 Infra at Section V.

34 The danger is easily overstated. As Hope noted (supra note 21 at 36):

[I]t is not to be reasonably anticipated that a policy thus carefully limited would breed overnight a nation of busy-bodies anxious to perform useless and meddlesome services for others and try their luck with the courts.

W.M. Landes \& R.A. Posner, "Salvors, Finders, Good Samaritans, and Other Rescuers: An Economic Study of Law and Altruism" (1978) 7 J. of Legal Stud. 83 at 93 [hereinafter "Salvors"].

While maritime salvors are often rewarded for rescue efforts (infra at III(D)), the danger of moral hazards is not significant. Scoundrels are dissuaded from creating perils by the fact that most ships are guarded against intruders at all times. Moreover, a salvor who is proven to have intentionally created a peril will be denied an award and can be held liable in damages for resulting losses: D.W. Steel \& F.D. Rose, eds., Kennedy's Law of Salvage 5th ed. (London: Stevens \& Sons, 1985) c. 10 [hereinafter Kennedy's]. See generally M. McInnes, "Life Rescue in Maritime Law" (1994), 25 J. Man. L. \& Com. (forthcoming) [hereinafter "Maritime"]. 
not be the case, however, if rescuers were permitted merely to recoup their actual expenses, and exceptionally to receive remuneration, ${ }^{36}$ such relief would reduce disincentives to intervention while removing incentives to misconduct.

Second, it has been suggested that a right of action would entail "horrendous" administrative costs. ${ }^{37}$ Assuming that a need for emergency assistance would typically be met, Landes \& Posner hold that relief would be sought every time a benefit was conferred; even those who would provide aid in the absence of a right of recovery would pursue relief. It is argued that once a peril has passed, altruistic impulses disappear or diminish, ${ }^{38}$ and rescuers revert to self-interested forms of behaviour. ${ }^{39}$

That argument is largely specious. ${ }^{40}$ In many situations, rescue entails few expenses. Consequently, if relief was limited to reimbursement, there would often be little motivation for a rescuer to enforce his right. ${ }^{41}$ Furthermore, claims that were made might be settled more quickly and less expensively than is often the case in civil litigation. A rescuee would not be in a position of defending himself against an accusation of wrongdoing; he would simply be asked to pay for a service for which he would probably be grateful. Additionally, some rescuers might place a high value on informal forms of compensation, such as public praise and self-esteem. Particularly if the amount of money at stake was small, they might prefer to ignore their legal rights in order to preserve the noble character of their actions. ${ }^{42}$ Finally, despite Landes \& Posner's assumption to the

Remuneration may be properly available to those who normally charge for their services: below at Section V(C).

See e.g. R. Posner, Economic Analysis of Law (Boston: Little, Brown \& Co., 1977) at § 6.9: "Salvors", supra note 35 at 120; W. Landes \& R. Posner, "Altruism in Law \& Economics" (1978) 68 Amer. Econ. Rev. 417 at 421 [hereinafter "Altruism"]. For an extended discussion of the issues involved on this point, see M. McInnes, "The Economic Analysis of Rescue Laws" (1992) 21 Man. L.J. 237 at 244-247 [hereinafter "Economic"].

A rescuer's marginal degree of altruism (i.e. the rate at which he is willing to exchange his own wealth for an increase in the wealth of a victim) is said to partially be a function of the relation between a rescuer's wealth and a victim's wealth: the larger the former relative to the latter, the more altruistic a rescuer will feel. So long as he is subject to a grave peril, a victim faces a threat of catastrophic loss and therefore has little wealth (regardless of the condition of his bank account). Once a peril has been removed, however, a victim's wealth increases dramatically, and a rescuer's marginal degree of altruism concomitantly decreases: "Altruism", ibid. at 418; "Salvors", supra, note 35 at 94. See also G.S. Becker \& G.J. Stigler, "Law Enforcement, Malfeasance and Compensation of Enforcers" (1974) 3 J. of Legal Stud. 1; G.S. Becker, "A Theory of Social Interactions" (1974) 82 J. of Poli. Econ. 82.

"Salvors", ibid. at 95; Posner, supra note 37 at § 6.9.

While overstated, Landes \& Posner's argument does sound an important note of caution. Occasionally, the administrative costs attendant upon a restitutionary rule might be quite high. If many rescuers participated in an effort, it could be difficult and costly to determine who helped and in what way. That may be a reason to limit the availability of remuneration (which is less easily quantified than is reimbursement) to professional salvors, with respect to whom it can easily be measured by reference to the fee that would normally be charged for similar services.

Similarly, because many rescue efforts require little effort, the right to recovery might often not be pursued even if remuneration was available.

Public acclaim often follows immediately upon the performance of a heroic act and dissipates quickly. Therefore, it might be somewhat immune to the dampening effect of a restitutionary claim, which would only need to be commenced within the relevant limitation period (cf. note 45). 
contrary, altruistic or charitable impulses may not disappear once an emergency comes to an end. Psychological evidence suggests that altruism is occasionally the product of a personality trait, and not simply a situational response. ${ }^{43}$

Finally, it might be said that relief for the life rescuer would open the law's gates to an unmanageable flood of claims. If recovery was allowed to those who save life, it could not be denied to those who, for example, preserve property. As will be seen, however, Anglo-Canadian law has allowed recovery to various types of necessitous intervenors, but has done so only in carefully confined circumstances. Even if the courts had not proven themselves capable of bridling relief in the area of life rescue, such claims would not necessarily be extended by analogy to other types of rescue. Logically, the principles underlying relief to a life rescuer might apply to other types of situations; in practice, legal principles are seldom followed to their theoretical limits. And in the present context, the courts would have little difficulty in identifying and justifying the boundary beyond which they would not proceed; between life and all other values runs a bright line established by the singularity with which human well-being is regarded.

\section{B. POLICY ARGUMENTS FOR ALLOWING RECOVERY}

The most desirable effect of allowing recovery would be an increase in the incidence of succour. ${ }^{44}$ By assuaging the fear of personal loss, the law could remove a disincentive to action. ${ }^{45}$ The extent to which the availability of relief would directly and significantly

Internally mediated rewards, on the other hand, may be more attuned to subsequent events; the heightened sense of self-esteem that one would feel after a rescue might be diminished or even negated if relief was ever sought: M. McInnes, "Psychological Perspectives on Rescue: The Behaviourial Implications of Using the Law to Increase the Incidence of Emergency Intervention" (1992) 20 Man. L.J. 657 at 677-679 [hereinafter "Psychological"].

The data is collected in J. Piliavin et al., Emergency Intervention (New York: Academic Press, 1981) c. 8.

44 Such is an aim of the Roman law doctrine of negotiorum gestio (below at note 53), which provides relief to necessitous intervenors in many jurisdictions.

The reason for [the doctrine] is the general convenience; otherwise people might be summoned away by some sudden event of pressing importance, and without commissioning anyone to look after and manage their affairs, the result of which would be that during their absence those affairs would be entirely neglected; and of course no one would be likely to attend to them if they were to have no action for the recovery of any outlay he may have incurred in doing so.

Justinian Institutes Bk III, tit. xxvii. s. 1, quoted in W.B. Williston, "Agency of Necessity" (1944) 22 Can. Bar Rev. 492 at 492-493.

The availability of restitutionary relief could paradoxically result in a reduction in the incidence of intervention. Internally, most people feel morally compelled to render assistance in an emergency. A coincidence of behaviour and beliefs will yield intrinsic rewards, such as feelings of selfsatisfaction and self-esteem, but only if an act is perceived to have been morally motivated. Extraneous inducements, whether positive or negative in nature, can lead to psychological overjustification; altruistic behaviour may be perceptually debased by an actor and attributed to external forces. If the external rewards do not sufficiently motivate, a particular action may become less common in time as the allure of self-rewards is removed. While intriguing in theory, overjustification has been found to be of relatively little importance in practice: "Psychological", supra note 42 at 677-679. For example, the effect would be undermined to the extent that people 
affect behaviour is, however, uncertain. It might be unrealistic to expect that such a rule would generally prompt intervention when moral and social forces urging action fail to do $50 .{ }^{46}$ On the other hand, the processes that determine a bystander's response to an emergency are complex and subtle; a rule allowing recovery could act in conjunction with other factors to create a psychological environment conducive to the decision to render assistance. $^{47}$

Even if it did not significantly affect behaviour, the availability of relief would be desirable insofar as it would allow a rescuer to recover from one upon whom he had unofficiously conferred a benefit: it would prevent an unjust enrichment. ${ }^{48}$ The proposal of this paper is not that all rescuers should enjoy a cause of action, nor that the relief granted should be particularly generous. However, as between two innocents, there are circumstances in which conscience calls for payment and which the law should honour through the imposition of liability.

Finally, the availability of relief may also be supported on the grounds that it would accord with common morality. Just as a duty to rescue has been characterized as part of the "shared morality of the community, ${ }^{149}$ most people may believe a right to restitution to be appropriate in the rescue context. If so, legal reform may be prudent, if only for self-interest. ${ }^{50}$

A system of law which lags too far behind the universally received conceptions of abstract justice, in the end must lose the sympathy, the confidence, perhaps even the respect of the community. ${ }^{51}$

The policy reasons for letting the costs of intervention lie where they fall are unpersuasive, while the arguments for shifting those costs onto the recipients of rescue

chose not to pursue relief.

The availability of relief might also remove a source of motivation and reduce the likelihood of intervention if bystanders believed that compensable rescue would not be the subject of public praise. The fact that a rescuer could choose to not exercise his right to relief would not entirely alleviate the concern. Social commendation often follows immediately upon a heroic act or not at all, and the mere possibility that recovery might be sought could lead others to doubt a rescuer's selflessness. However, it is easy to overestimate the behaviourial impact of such a theory. To be relevant, a bystander would have to believe that others would withhold praise, and the resulting loss in motivation would have to cause him to refuse succour despite the motivational gain produced by the right to restitution. It might be otherwise if rescuers were granted rewards, and not merely reimbursement or remuneration. As evidenced by the existence of professional maritime salvage firms, the law can influence behaviour by appealing to greed: below at Section III(D). Unfortunately, rewards would engender moral hazards, could prove harsh on individuals who receive services and might entail substantial administrative costs: above at Section II(A). "Psychological", supra note 42 at 685; Piliavin, supra note 43.

Maddaugh \& McCamus, supra note 11 at 53.

49 A.M. Honore, "Laws, Morals and Rescue" in J.M. Ratcliffe, ed., The Good Samaritan and the Law (Gloucester, Mass.: Peter Smith, 1981) 225 at 227-228.

so Because people often perceive the law as an indifferentiated mass, they may lose respect for it as a whole if they feel that it is inconsistent with morality in one particular area: Honore, ibid. at 239-240.

s1 F.H. Bohlen, "The Moral Duty to Aid Others as a Basis of Tort Liability" (1908) 56 U. Pa. L. Rev. 217 and 316 at 337 . See also B. Cardozo, The Paradoxes of Legal Science (New York: Columbia University Press, 1928) at 25. 
services are attractive. However, it remains to be shown that relief for the life rescuer could be controlled in an effective and principled manner. By way of introduction to a study of the appropriate conditions and limitations on such relief, it will be useful to consider how the law responds to the claims of necessitous intervenors in analogous situations.

\section{RELIEF FOR NECESSITOUS INTERVENORS ${ }^{52}$}

While a general right to restitutionary relief for the life rescuer has yet to be recognized in Anglo-Canadian law, ${ }^{53}$ in certain circumstances, recovery has been granted to those who act for the preservation of another's life or health. ${ }^{54}$

\section{A. EMERGENCY AID BY A PHYSICIAN}

Though unparalleled in English law, there is Canadian authority ${ }^{55}$ for the proposition that a physician may recover remuneration for his rescue efforts. ${ }^{56}$ This position is not

The ensuing discussion is illustrative only. For a more detailed examination of the law in the various areas, see Maddaugh \& McCamus, supra note 11; Goff \& Jones, supra note 13.

In contrast, many jurisdictions, including Quebec (Civil Code Art. 1043-1046; J. Baudoin, Les Obligations (Montreal: Les Presses de L'Universite de Montreal, 1970) at 203-209) and Scotland (D.M. Walker, Principles of Scotrish Private Law 4th ed. (Oxford: Clarendon Press, 1988) at vol. II, Bk. IV, 513-514) employ the Roman law concept of negotiorum gestio, which generally permits a stranger to unofficiously intervene for the management of another's affairs and to receive compensation. See generally D.H. Van Zyl, Negotiorum Gestio in South African Law (Natal: Butterworths, 1985); Dawson, supra note 32.

While the exact scope of the negotiorum gestio doctrine varies between jurisdictions, it is generally premised upon several conditions: (i) there must be an emergency which a victim is unable to meet himself; (ii) a gestor must act in the absence of any pre-existing duty or authority; (iii) a gestor must act reasonably; and (iv) a gestor must act in the best interests of a victim. If those conditions are met, a gestor will be granted reimbursement, though generally not remuneration, as she is assumed to have acted with a gratuitous intent. It may be otherwise, however, if a gestor renders a service for which she habitually charges. Finally, though an unauthorized interference with another's affairs is normally actionable, a gestor's conduct is generally considered lawful. Nevertheless, she will be held liable for egregious errors and misconduct.

While Anglo-Canadian law does not recognize a general principle identical to the doctrine of negotiorum gestio, it does not often grant relief to necessitous intervenors on bases similar to those noted above: cf. M.L. Marasinghe, "The Place of Negotiorum Gestio in the Common Law" (1976) 8 Ottawa L. Rev. 573 at 586-587.

The relief granted is not invariably restitutionary.

In the United States, restitutionary relief has been granted to not only physicians (Cotnam v. Wisdom, 83 Ark. 601, 104 S.W. 164 (Ark, S.C., 1907); Edson v. Hammond, 142 N.Y. App. Div. 693 (1911), but also to public hospitals (In Re Crisan Estate, 362 Mich. 569, 107 N.D. 2d 907 (1961) and nursing homes (In Re Estate of Anderson, 119 Misc. 2d 248, 462 N.Y.S. 2d 589 (1983). See G.E. Palmer, The Law of Restitution, Vol. II (Boston: Little Brown \& Co., 1978) at § 10.4; Restatement, supra note 10 at $\$ 116$.

Today, the issue is unlikely to arise between physicians and patients; remuneration is apt to be paid by the state: see e.g. Alberta Healih Care Insurance Act, R.S.A. 1980, c. A-24, s. 5.2(6); National Health Service Act 1977 (U.K.), 1977; but see Medical Service Act, R.S.B.C. 1979, c. 255; British Columbia Regs. 144/68, Reg. 5.10; Road Traffic Act 1988 (U.K.), 1988, s. 158. 
surprising given the strong policy considerations favouring the provision of emergency services by professional care givers. ${ }^{57}$

Matheson v. Smiley ${ }^{58}$ arose after M, a physician, attended to S, who had attempted suicide with a shotgun. Though his services were unavailing, $M$ claimed $\$ 150$ in remuneration from S's estate. The defendant resisted on the grounds that: (i) the services had not been requested, but rather refused, by S; (ii) M's efforts were obviously doomed from the outset; and (iii) the amount of remuneration sought was excessive. The Manitoba Court of Appeal held for the plaintiff. Robson J.A. brushed aside the fact that the services had not been the subject of a contract or a request, noting that the deceased had been in "no shape" to enter into legal relations anyway, and asserting that it was not within reason that a person should simply be permitted to die. Similarly, it was irrelevant that the services were predictably unsuccessful; $M$ had nevertheless provided a "necessary" service to $\mathrm{S}$. Finally a fee of $\$ 150$ was held to be reasonable given the standing of the plaintiff and the position in the life of the deceased.

The decision raises many interesting issues. First, to what extent should the law respect an individual's freedom to choose his own destiny; should recovery be denied if a victim exhibits a desire to die? Second, should recovery be available to a rescuer even if his services are unavailing? Third, the court assumed that the plaintiff had acted with an intention to charge for his services. Should such an intention be necessary, and if so, should it ever be presumed? Finally, assuming that relief should be available, on what basis should it be quantified? Those issues are fully explored below.

Another instructive case is Soldiers Memorial Hospital v. Sanford. ${ }^{59}$ In the course of an altercation with the police, $\mathrm{S}$ was bruised about the head and shot in the groin. En route to jail, the police took $S$ to a hospital for treatment. The hospital sought to recover the value of their services from $\mathrm{S}$, but the claim was rejected. The ratio of the decision turned narrowly on the fact that a public authority charged with the expense of operating a jail must pay for medical services required by a person under arrest. ${ }^{60}$ In dicta,

For the same reason, a tort action for assault will generally not lie against a doctor who provides nonconsensual medical aid in an emergency: Marshall v. Curry, [1933] 3 D.L.R. 260; F. v. West Berkshire H.A., [1989] 2 All E.R. 545. It will be otherwise, however, if a patient refuses treatment (Malette v. Shulman (1987), 47 D.L.R. (4th) 18, aff'd 67 D.L.R. (4th) 321), or if a procedure is performed merely for the sake of convenience: Murray v. McMurchy, [1949] 2 D.L.R. 443.

[1932] 2 D.L.R. 787. A similar American decision is Myer v. Knights of Pythias, 178 N.W. 63, 70 N.E. 111 (1904).

Given the paucity of case law on point, it is understandable that academics have made much of Matheson v. Smiley: Maddaugh \& McCamus, supra note 11 at 692-693; Goff \& Jones supra note 13 at 342-343; G.H.L. Fridman \& J.G. McLeod, Restitution (Toronto: Carswell, 1982) at 497-499. From a practical perspective, however, there is a danger of overstating the importance of the decision. It is, after all, but one opinion, and cannot be said to have conclusively established a right of recovery. A similar decision (Hastings v. Semans Village, supra note 6) can be explained on the narrower grounds of agency of necessity or fulfilment of another's duty: infra at note 91.

a) The irony of the majority's decision was not lost upon Ross J. in dissent. If $\mathrm{S}$ had simply fallen ill in the street and been taken to the hospital by the police, he would have been liable for the cost of the services. However, because he was injured while committing an act for which he was arrested, 
however, it was accepted that under normal conditions, a person who receives emergency medical aid from a physician or hospital will be liable for remuneration, subject to certain limitations. Thus, while it went astray in applying the principles to the facts, ${ }^{61}$ the court recognized that a rescuer's claim will fail if he was an inappropriate person to act or if the victim had effectively refused his services. ${ }^{62}$

\section{B. ROAD TRAFFIC ACT 1988, (U.K.)}

The Road Traffic Act 1988, (U.K.) allows English doctors and hospitals to recover for services rendered with respect to injuries connected with automobiles. ${ }^{63}$ A fixed fee per person treated and nominal travelling costs can be charged to the individual using a vehicle when a casualty occurs. The right of recovery is not always restitutionary in nature; the services may not have enriched the defendant as treatment may have been provided to another person who innocently suffered an injury.

\section{THE SUPPLY OF NECESSARIES ${ }^{64}$}

Restitutionary relief ${ }^{65}$ is available to one who supplies necessaries of life ${ }^{66}$ to a person incapacitated by mental incompetency, infancy or drunkenness. The scope of recovery is, however, limited. ${ }^{67}$ There must be an actual, as opposed to an apparent, necessity; a plaintiff must be an appropriate person to act; intervention must be in the best interests of the incapacitated person; and a plaintiff must be acting with an intention of being reimbursed or remunerated. ${ }^{68}$

he was entitled to free medical aid.

Graham J. fell prey to the "implied contract" theory of restitution (above at note 15), spoke of the defendant's capacity to enter into legal relations, and held that $S$ 's protests at being taken to the hospital were sufficient to preclude liability because they prevented the inference of an implied contract. Ross J., in dissent, more persuasively argued that S's protests should be considered irrelevant as being the views of a person in extremity.

See also Mulloy v. Hop Sang, [1935] 1 W.W.R. 714 (Alta. S.C.).

Road Traffic Act 1988 (U.K.), 1988, supra note 56 at s. 158. There is no equivalent Canadian provision.

Though suffering from a general contractual incapacity, individuals who are mentally incompetent, underage or drunk are capable of contracting for the necessities of life. Furthermore, if they enter into an unenforceable contract, they will still be liable on restitutionary grounds for goods or services received: Maddaugh \& McCamus, supra note 11 at c. 14; Goff \& Jones, supra note 13 at c. 22. The discussion that follows concerns another type of case, i.e. that in which necessaries of life are provided without request to an incapax.

Re Rhodes, Rhodes v. Rhodes (1890), 44 Ch.D. 94 at 105, Cotton J. [hereinafter Re Rhodes]. The term "necessaries of life" defies precise definition. It generally refers to food, shelter, clothing and medical care, but it may also encompass other matters, according to the incapacitated person's needs, means and station in life. Thus, in Samilo v. Phillips (1968), 69 D.L.R. (2d) 411 (B.C.S.C.) the payment of tax liabilities gave rise to a right of reimbursement.

See Maddaugh \& McCamus, supra note 11 at 693-696; Goff \& Jones, supra note 13 at 344-347. In the leading case of Re Rhodes, supra note 65 , a brother and nephew incurred expenses over many years to maintain a disabled woman. On her death, an action was brought for reimbursement. The Court of Appeal recognized that recovery could lie in a proper case, but rejected the plaintiff's claim. The evidence indicated that when the payments were made, there had not been an intention to create a debt against the woman's estate; no claim had been made during her lifetime and no accounts had been kept. See also Re Hilker (1924), 55 O.L.R. 402. 


\section{MARITIME SALVAGE ${ }^{69}$}

Admiralty courts have long enjoyed a special jurisdiction to grant to maritime salvors not only reimbursement and remuneration, but also reward. ${ }^{70}$ The availability of such relief is premised upon several conditions: ${ }^{11}$ (i) a claimant must be a member of a recognized class of salvor; ${ }^{72}$ (ii) services must be rendered within specified geographical locations; (iii) the subject of salvage must be endangered; (iv) services must be rendered in the interests of a salvee; (v) a benefit must be conferred; ${ }^{73}$ and (vi) the intended object of benefit must be a recognized subject of salvage.

Traditionally, life salvage was awarded only if a rescuer also salvaged property on the same occasion. That situation has been statutorily altered, and courts may now grant awards to independent life salvors - i.e. individuals who rescue life on occasions when others rescue property ${ }^{74}$ In such cases, liability falls entirely upon the owners of salved property; salvage is never payable by a person whose life has been spared. ${ }^{75}$ Furthermore, in cases of pure life salvage (i.e. when no property has been salved), the government may exercise its discretion to grant awards from public funds. ${ }^{76}$

It has been suggested that those who supply necessaries of life should not have to positively prove an intention to charge for their expenses or efforts: Goff \& Jones, supra note 13 at 346; Maddaugh \& McCamus, supra note 11 at 695; Re McKeown, [1962] O.R. 142 at 145. A similar rule may be apposite in the rescue context: below at Section IV(C). See generally "Maritime", supra note 35.

While the primary basis of salvage awards is the principle of unjust enrichment (Kennedy's, supra note 35 at 18), the measure of relief is inflated as a means of encouraging intervention: Gurney v. MacKay (1875), 37 U.C.Q.B. 324 (Ont. C.A.); The Telemachus, [1957] 2 W.L.R. 200.

Though he qualifies for an award, a salvor's exact measure of relief will be a function of many factors, such as the degree of competence exhibited and the value of property salved: Kennedy's, supra note 35 at $458-459$.

A person will be recognized as a salvor if he acted voluntarily (i.e. in the absence of a pre-existing legal duty) and did not act solely in self-interest. However, he will not be denied the status of a salvor merely because he fulfils one of the statutory obligations that require the provision of emergency assistance: Maritime Conventions Act 1911, (U.K), 1911, s. 6(1)(2); Canada Shipping Act R.S.C. 1985, c. S-9, s. 45(1)(2) (rescue of persons found at sea); Merchant Shipping (Safety Convention) Act 1949, (U.K.), 1949, Canada Shipping Act, s. 384(6) (response to distress signals); Merchant Shipping Act 1894, (U.K.), 1894, s. 422, Canada Shipping Act, s. 568; Canadian Criminal Code, R.S.C. 1985, c. C-46, s. 252 (assistance by ships involved in collisions).

Two reasons underlie the requirement of success. First, insofar as salvage awards are based on a principle of unjust enrichment, maritime courts consider relief to be justifiable only if an actual benefit is conferred: cf. Section IV(E). Second, a salvage claim was historically an action in rem as liability was satisfied by a means of a lien on salved property. In the absence of arrestable property, an action could not be maintained: The Fusilier (1865), 3 Moo. P.C. (N.S.) 51 at 56; The Cargo ex Schiller (1877), 2 P.D. 145 at 149, aff'g. (1876) 1 P.D. 473.

Merchant Shipping Act 1894 (U.K.), s. 544 (as am.); Canada Shipping Act, supra note 72 at s. 450. Article 9 of the Brussels Convention on Salvage 1991 states: "No remuneration is due from persons whose lives are saved...."

Merchant Shipping Act 1894, (U.K.), 1894, supra note 74 at s. 544(3); Canada Shipping Act, supra note 72 at s. 450(3). The same possibility holds true for independent life salvors when the value of salved property is insufficient to satisfy all claims. Though remarkable in theory, the provisions are seldom employed in practice: Kennedy's, supra note 35 at 115, n. 52. 
The fact that the immediate beneficiaries of life salvage are never subject to liability distinguishes the rule applicable in the maritime context from the rule proposed in this paper. Because salvage rewards are satisfied from public funds or salved property (or, more realistically, insurance policies), large measures of relief can be granted without fear of imposing a financially crippling burden. In contrast, there would not be property from which judgments in favour of land based rescuers could be satisfied; ${ }^{77}$ similar awards would fall personally and heavily on innocent victims. ${ }^{78}$ Moreover, it may not be as necessary to encourage inland, as compared to maritime, intervention; state funded rescuers are more readily available on land than at sea. ${ }^{79}$

\section{E. FULFILMENT OF ANOTHER'S DUTY}

A necessitous intervenor who acts in fulfilment of another's duty may be entitled to relief. Occasionally, a person charged with burying a body will fail to fulfil his obligation, ${ }^{80}$ and for reasons of public decency and safety, it will become necessary for a stranger to deal with a corpse. An intervenor will have a restitutionary claim against a higher obligee for reimbursement or remuneration ${ }^{81}$ if he unofficiously ${ }^{82}$ acts in a manner befitting the deceased and without an intention to confer a gift.

Similarly, restitutionary relief is available to a necessitous intervenor who unofficiously fulfils an obligation imposed upon a public body for the purpose of public health or safety. ${ }^{83}$ Thus, in Simmons v. Wilmott, ${ }^{84}$ a stranger who rendered medical treatment to

The possibility of compensating land based rescuers from public funds is considered below at Section $\mathrm{V}(\mathrm{A})$.

78 Such a situation could have behaviourally undesirable consequences. The fear of financially ruinous liability could engender excessive caution among potential victims: "Economic", supra note 37 at 265. Conversely, it has been argued that potential victims would be excessively careless if they were not subject to liability, but were owed a duty to rescue. "Salvors", supra note 35 at 124; D. Wittman, "Liability for Harm or Restitution for Benefit?" (1984) $13 \mathrm{~J}$. of Legal Stud. 57 at 70, fn. 37. It is doubtful that the latter possibility would occur. At least in regards to personal injury, an individual is unlikely to unnecessarily court danger simply because a bystander may be liable to him for failing to render assistance.

There are "normally no public services such as fire brigades [at sea]": The Goring, [1987] Q.B. 687 at 710, Ralph Gibson L.J. Consequently, if the likelihood of life rescue at sea is to be comparable to that on land, the availability of rewards is necessary to ensure the economic viability of private maritime salvage firms.

The primary duty belongs to the deceased's personal representative. Secondary obligations may be imposed upon the deceased's spouse or parents, the owner of a house in which he or she passed away, or the municipality in which he or she died.

The intervenor may be one who paid to have a body interred or an undertaker who performed a service himself: Roger v. Price (1829), 3 Y. \& J. 28, 148 E.R. 1080; Davey v. Rural Municipality of Cornwallis, [1931] 2 D.L.R. 80, [1931] 1 W.W.R. 1 (Man. C.A.).

Recovery will be denied if an intervenor acted in the knowledge that a more appropriate person was ready, willing and able to undertake the service: Patterson v. Patterson, 17 Am Rep. 384 (N.Y. 1875); Quinn v. Hill, 4 Dem. 69 (N.Y. 1866). discharge its obligation: Holborn Union v. Shoreditch Vestry (1876), 23 Q.B.D. 145, 46 L.J. Q.B. 36; cf. Macclesfield Corp. v. Great Central Ry, [1911] 2 K.B. 528, 104 L.T. 728 (C.A.). 
a pauper was permitted recovery from a parish authority charged with the responsibility of caring of the poor. As always, however, the courts are vigilant to discourage officious meddling; recovery is denied if an intervenor did not avail himself of a reasonable opportunity to inform the public body of the need for services.

A similar rule might permit recovery by one who fulfils another's spousal or parental duty of care. There is little authority on point, largely for reasons which are now of historical significance only, ${ }^{85}$ and because an unfulfilled obligation will today typically be performed by the state. Though the proposal has yet to be taken up by the courts, restitutionary relief should be available to a necessitous intervenor who unofficiously ${ }^{86}$ provides for another's spouse or child. ${ }^{87}$

\section{F. AGENCY OF NECESSITY ${ }^{88}$}

The doctrine of agency of necessity originated in the maritime context, and permitted a ship's master to deal with his vessel and its cargo during an emergency in a manner that fell outside the ordinary scope of his authority. If he acted reasonably and in the best interests of the parties concerned, and if communication with the owners of the property was practically impossible or ineffectual, then he could recover his expenses. In time, the doctrine was extended to carriers on land ${ }^{89}$ and to certain situations ${ }^{90}$ involving preexisting relationships. ${ }^{91}$

At common law, a husband's duty to support his wife was largely unenforceable because of the nowabolished rule prohibiting inter-spousal actions. With respect to even legitimate, minor children, a father either had no duty (Mortimore v. Wright (1840), 6 M. \& W. 482; Cleaver v. Cleaver, [1949] 4 D.L.R. 367 (C.A.)) or a duty that was entirely unenforceable: P.M. Bromley \& N.V. Lowe, Family Law, 8th ed. (London: Butterworths, 1992) at 651. Spousal and parental duties have now been expanded and put on a statutory basis: see e.g. Family Law Act 1986, (U.K.) S.O. 1986, c. 4, ss. 3031; Canadian Criminal Code R.S.C. 1985, c. C-46, s. 215; Supplementary Benefits Act 1976, (U.K.), 1976, s. 17 (as am.); National Assistance Act 1948, (U.K.), 1948, s. 42.

Though questionable on its facts, the American case of Greenspan v. Slade, 97 A. 2d 390 (N.J. S.C., 1953) illustrates the proposition. A girl hurt her foot, but her parents believed the injury to be a mere sprain. An acquaintance took the girl to the plaintiff physician, who, without consulting the parents, diagnosed the injury as a fracture and applied a cast. The court held the parents liable to the physician. Arguably, recovery should have been denied because the plaintiff did not act in response to an urgent need, and should have communicated with the parents. See also Lufkin v. Harvey, 131 Minn. 238, 154 N.W. 1097 (1915); Baker v. Baker, 169 Tenn. 589, 89 S.W. 2 d 763 (1935). Maddaugh \& McCamus, supra note 11 at 705-707; Goff \& Jones, supra note 13 at 347-348. See generally, Williston, supra note 44; G.H.L. Fridman, The Law of Agency, 5th ed. (Toronto: Butterworths, 1983) c.7; F.M.B. Reynolds, ed., Bowstead on Agency, 15th ed. (London: Sweet \& Maxwell, 1985) at 84-90.

Thus, in Walker v. Great Western Ry. Co. (1867), L.R. 2 Ex. 228, a railway was ordered to reimburse an employee who contracted on his employer's behalf for the provision of emergency medical services for a passenger. See also Northern Railway Co. v. Swaffield (1874), L.R. 9 Exch. 595.

See e.g. The Winson, [1982] A.C. 939 (H.L.) (bailment). The doctrine also finds application in regards to acceptors of bills of exchange: Hawtayne v. Bourne (1841), 7 M. \& W. 595, 151 E.R. 905. In Hastings v. Village of Semans, [1946] 4 D.L.R. 695, S, an injured indigent woman, was treated by $\mathrm{H}$ and taken to the plaintiff's hospital. $\mathrm{S}$ was unable to pay for the services, and a claim was brought by the plaintiff against the village in which she was resident, and which had a statutory duty to care for her. Coincidentally, $\mathrm{H}$ was the medical officer of the defendant village. Recovery was properly allowed, but the court's reasoning was unsatisfactory insofar as it held that $\mathrm{H}$ had acted as 
In Prager v. Blatspeil, Stamp \& Heacock Ltd., ${ }^{92}$ McCardie J. indicated that the doctrine of agency of necessity might enjoy an even broader application:

[T] here is nothing in the existing decisions which confines the agency of necessity to carriers whether by land or sea, or to the acceptors of bills of exchange. The basic principle ... is a broad and useful one. It lies at the root of the various classes of cases of which the carrier decisions are merely an illustration.

The logic of his position might be stretched to encompass situations in which an intervenor (whether of property or life) did not share a pre-existing relationship with a victim. ${ }^{93}$ On that view, justification for relief would lie not in the presence of a preexisting relationship, but in the fact that a necessity elicited an unofficious ${ }^{94}$ and beneficial response. ${ }^{95}$

It would be neither easy nor desirable to enlarge the scope of the doctrine to include a rescuer who did not enjoy a pre-existing agency relationship with the beneficiary of his actions. ${ }^{96}$ First, McCardie J.'s expansive view has been doubted in the House of Lords. ${ }^{97}$ Second, it would be inappropriate to apply some incidents of an agency (e.g. tortious liability for the principal on the basis of the agent's actions) in the absence of a pre-existing relationship. Third, because rescuers sometimes receive relief on other grounds, ${ }^{98}$ the use of the agency of necessity doctrine would introduce analytical

an "agent of necessity" for the defendant village in bringing $S$ into the plaintiff's hospital for treatment. It is unlikely that the incidents of the relationship between $\mathrm{H}$ and the defendant extended to the type of services undertaken. Moreover, the evidence did not suggest that $\mathrm{H}$ considered his actions to be those of an agent: Maddaugh \& McCamus, supra note 11 at 688-689.

Recovery by both the plaintiff hospital and $\mathrm{H}$ (insofar as he rendered services outside the scope of the duties he owed to the defendant) would today be better based on the fact that they unofficiously discharged the statutory obligation of the defendant village: County of Carleton v. City of Ottawa, [1965] S.C.R. 663. [1924] 2 K.B. 566 at 570.

In cases involving a pre-existing relationship, an agent's right of recovery may be seen simply as an implied extension of his actual authority: see e.g. Fridman \& McLeod, supra note 58 at 489-490; Maddaugh \& McCamus, supra note 11 at 686; cf. Goff \& Jones, supra note 13 at 336. Birks has suggested that the relevance of a pre-existing relationship may lie simply in the fact that it negatives voluntariness in much the same way that the public interest in decency and health negatives voluntariness in the burial cases: supra note 13 at 130; cf. note 30 .

Though confining the agency of necessity doctrine to situations involving a "contractual or other preexisting legal relationship" (supra note 13 at 332), Goff \& Jones argue that agency of necessity cases and disparate other cases in which recovery has been allowed are based on a single, unifying principle: "[O]ne who intervenes on another's behalf in an emergency should within...limits...be treated as though he had the authority of that person to intervene": supra note 13 at 350.

In a similar vein, Lord Goff has suggested that a physician who acts without a patient's consent in an emergency may have a defence to an action in tort because "the necessity itself provides the justification for the intervention": F. v. West Berkshire H.A., supra note 57 at 567. See e.g. Maddaugh \& McCamus, supra note 11 at 691-692. Jebara v. Ottoman Bank, [1927] 2 K.B. 254 at 271, Scrutton L.J. (confining the doctrine to cases involving a pre-existing agency relationship); The Winson, supra note 90 at 958 , Lord Diplock. 
inconsistency and confusion. Finally, the considerations that should guide relief for the rescuer are not invariably those that underlie the doctrine of the agency of necessity. ${ }^{99}$

\section{CONDITIONS FOR RECOVERY BY LIFE RESCUERS}

The preceding discussion illustrated that necessitous intervenors are occasionally permitted recovery in Anglo-Canadian law, but also that relief is generally premised on certain conditions: (i) the existence of an emergency necessitating assistance; (ii) an unofficious act of intervention; (iii) the presence of a particular intention on the part of the intervenor; (iv) the performance of reasonable actions; and (v) the attainment of some measure of success. The aim of the present section is to determine the extent to which a general rule allowing recovery by life rescuers should be governed by those same conditions. $^{100}$

\section{A. EMERGENCY}

Clearly, a rescuer should be permitted recovery only if he acts in response to an emergency. But how grave and probable should an apprehended harm have to be? What degree of urgency should be insisted upon? Answers to these questions turn on an assessment of the relative importance of competing policy considerations. If emphasis is placed upon a defendant's freedom to control his own purse strings, it will seem appropriate to restrict the availability of relief. Thus, liability might lie only for services rendered in response to a threat of imminent, certain and grievous harm. In contrast, as the focus shifts to the desirability of encouraging intervention and reversing enrichments, a lower threshold will appear appropriate.

An apposite test, consistent with the law in analogous areas ${ }^{101}$ and fair to both parties, would permit recovery if a peril was such that a reasonable person would have believed intervention to be justified. ${ }^{102}$ The courts should not view the matter with the benefit of

For example, while reimbursement may be available to an agent of necessity even though he fails to confer a benefit, some commentators have argued that one who attempted to rescue life should not receive relief if he is unsuccessful: below at Section IV(E).

Some of the conditions may be conceptualized either as elements of a prima facie claim or as defences to an otherwise successful action. Consequently, the placement of the burden of proof may be crucial.

In the context of maritime salvage, it is enough that there is a misfortune, or a possibility of a misfortune, which would have exposed property or life to the possibility of injury or loss if services were not rendered: The Charlotte (1848), 3 W. Rob. 68 at 71, 166 E.R. 888. While insisting upon a probability, rather than a mere possibility, of harm in regards to rescuers of property on land, Jones has argued that the maritime standard is proper with respect to rescuers of life on land: supra note 5 at 145,159 . However, restitution should not be possible if a peril existed merely as a fanciful or vague possibility.

An agent of necessity need only prove that it was reasonable for him to act in the circumstances, not that he was subject to a necessity in the sense of an irresistibly compelling force: Australian Steam Navigation Co. v. Morse (1872), L.R. 2 P.C. 222 at 230.

Arguably, it would be desirable to permit relief even if a peril was merely perceived to have existed; such a rule would provide greater encouragement for bystanders. However, such a rule would be difficult to rationalize in terms of unjust enrichment (below at Section IV(E)) or justify from a 
hindsight:;03 relief should not be denied simply because it is apparent after the fact that a peril would have been averted by some other force had the rescuer not intervened. Nor should relief be denied merely because a necessity was of a continuing nature. ${ }^{104}$ Finally, the onus of proving the existence of an emergency should be on the rescuer. ${ }^{105}$

\section{B. OFFICIOUSNESS AND APPROPRIATENESS OF INTERVENTION}

Relief may properly be denied on the grounds of officiousness notwithstanding the existence of an emergency; while crying out for assistance, a peril may speak selectively. Though a rescuer may be fully capable of rendering reasonable services, it may nevertheless be unreasonable for him to take action. Bearing in mind the twin dangers of encouraging meddlesomeness and unduly infringing freedom, a rule granting recovery must be carefully limited.

\section{Suitability of Rescuer as Intervenor}

It should suffice that a rescuer was an appropriate person to act; he should not be required to prove that he was the appropriate person to act. The more restrictive formulation would work to the detriment of victims by discouraging intervention by bystanders who could provide assistance. ${ }^{106}$ So too would it be unfair to a rescuer who reasonably took action only later to learn that a more appropriate salvor had been summoned. Finally, the search for the most appropriate intervenor could involve the courts in an unnecessarily complex and protracted inquiry, thereby increasing the administrative costs of litigation.

A court should view the facts of a peril as they could reasonably have been perceived during an emergency, and ask if it was appropriate for the plaintiff to have become involved. Certain factors would tend to favour or militate against an affirmative answer. Thus, the fact that a rescuer and a victim shared a pre-existing relationship would often

victim's perspective. The test described in the previous note, based on an actual peril, strikes a fair balance between the competing policy considerations.

In contrast, a rescuer may recover in tort, against a person who negligently creates the mere perception of a peril, for injuries or losses sustained while responding to such a perception: above at note 3.

Such a rule obtains under the doctrine of agency of necessity: The Winson, supra note 90 at 965 , Lord Simon.

Thus, relief should be possible though a victim could have survived for some time without a rescuer's efforts if the situation was sufficiently grave and if immediate intervention was reasonable in the circumstances.

A maritime salvor will not be denied an award simply because he acted with respect to a continuing emergency: Kennedy's, supra note 35 at 149-154.

Such is the rule in the law of maritime salvage: The Wilhelmine (1842), 1 Not. of Cas. 376; Iron Mac Towing (1974) Ltd. v. The North Arm Highlander, 24 Feb. 1978, Act. No. T-3944-76, Fed. T.D. aff'd. (1979) 28 N.R. 348 (Fed. C.A.).

Fearful of incurring a large and irrecoverable cost, a rescuer might hesitate to intervene if he thought that a court might later identify someone else who would have been better suited to providing assistance. Consequently, a victim might not receive adequate aid from anyone. 
indicate the appropriateness of intervention. ${ }^{107}$ Indeed, in some cases, it would settle the issue of recovery, one way or the other ${ }^{108}$ For example, a potential victim may enter into a contractual relationship with another person, such as a lifeguard, for the very purpose of receiving emergency care. ${ }^{109}$ The terms of such a relationship will call for both intervention and payment, and the issue of restitutionary relief generally will not arise. $^{110}$

It would occasionally be proper to reject a plaintiff's claim because he was an (or even the) appropriate person to intervene; a person may come under a duty to rescue, by reason of which he should be denied recovery. The issue admits of no easy answer, for in the absence of fault ${ }^{11}$ it is always difficult to determine which of two innocents ought to bear a loss. A resolution of the issue demands a sensitive balancing of interests. As usual, consideration must be given to the desirability of encouraging intervention, reversing unjust enrichments, and allowing victims to control their own purse strings. But, the law must also protect the freedoms of rescuers. Should a person compelled to render assistance on pain of liability also be compelled to potentially suffer a financial loss? The answer lies in the origin of the particular obligation.

The fact of a pre-existing relationship would not invariably be determinative; the nature and purpose of a relationship might be of little or no relevance to the issue at hand. Thus, the fact that a rescuer and a victim stood in a dentist-patient relationship should not preclude a court from holding that it was inappropriate for the former to attend to the latter's stomach wound if a more aptly trained rescuer was at hand. However, given the desirability of encouraging intervention, the courts should lean toward rulings favourable to rescuers.

In practice, many relationships would preclude the issue of recovery from ever arising. Thus, while it would often be appropriate for a wife to rescue her husband, she might not be moved to pursue relief. Conceivably, it might be otherwise if liability would be borne not by the husband, but rather by his insurer or estate.

As will be discussed shortly, a pre-existing relationship might also preclude a claim for recovery if it involves a duty to rescue.

The Canadian formulation of the unjust enrichment principle permits recovery only if there is an "absence of any juristic reason - such as contract or disposition of law - for the enrichment": Rathwell v. Rathwell, supra note 12 at 455 [emphasis added].

Weston v. Downes (1778), 1 Dougl. 23; Toussaint v. Martinnant (1787), 2 T.R. 100; Gompertz v. Denton (1832), Cromp. \& M. 207; Goff \& Jones, supra note 13 at 31-32.

A relationship may entail a compensable obligation to provide assistance, but a rescuer's efforts may be supererogatory, and hence properly the subject of additional relief. An analogy appears in the law of maritime salvage. Crewmen are generally precluded from claiming salvage for services rendered to their own vessel because of an implied contractual term that requires them to use their best efforts to preserve her in times of peril: The Albionic (1941), 70 L.L.R. 257. Nevertheless, salvage awards are available to crewmen who do more than is contractually required: Newman $\mathbf{v}$. Walters (1804), 3 B. \& P. 612; Kennedy's, supra note 35 at 196-197; cf. The Florence (1852), 16 Jur. 572 at 575 .

In limited circumstances, a life rescuer who is party to a pre-existing relationship might be granted relief for supererogatory efforts on the basis of the doctrine of agency of necessity, rather than on the basis of the general rule advocated in this paper: above at Section III(G).

iII A rescuer has a right of recovery in tort law if he incurs a loss while intervening in a negligently created peril: above at note 3 . 
If actions were taken pursuant to a general duty to rescue, ${ }^{112}$ considerations of fairness would favour a right to relief. ${ }^{113}$ The primary purpose of such an obligation would be an increase in the incidence of succour, not a re-distribution of wealth. Furthermore, the requirement of action would typically place demands upon a person by a twist of fate, by his being in a particular place at a particular time. There would be nothing in his conduct to suggest that he expressly or implicitly assumed an obligation which would vitiate the merit of his claim. ${ }^{114}$ Similarly, there would be little to which a victim could point to establish the justice of denying relief. ${ }^{115}$

The matter would take on a different complexion if an obligation was voluntarily assumed, rather than forcibly imposed; in such circumstances, the stick and the carrot should not go together. ${ }^{116}$ A person who freely chose to bear a responsibility would find it relatively difficult to argue that she should not suffer the costs attendant upon its fulfilment. The voluntary assumption of an obligation would explain, in a way that would militate against the recognition of an "unjust" enrichment, why services were rendered. Thus, an intervenor should be forced to look elsewhere for compensation if she acted, for example, in the capacity of a privately hired lifeguard or a state funded rescuer. ${ }^{17}$ But the issue should not turn simply on the availability of alternative forms of compensation. Occasionally, it would be proper to deny relief even though a rescuer's duty was not

Though it has yet to be introduced, such a duty has been the subject of numerous proposals: see e.g. "Duty", supra note 2.

Jones argues that the presence of a criminally sanctioned obligation facilitates the availability of restitutionary relief; supra note 5 at 156-158. In many civil jurisdictions, including Quebec, a right of recovery under the doctrine of negotiorum gestio (above at note 53) coexists with a general duty to rescue: The Charter of Human Rights and Freedoms, R.S.Q. 1977, c. C-12, s. 2; A. Rudzinski, "The Duty to Rescue: A Comparative Analysis" in J. Ratcliffe, ed., The Good Samaritan and the Law (Gloucester, Mass.: Peter Smith, 1981) at 92; F. Feldbrugge, "Good and Bad Samaritans: A Comparative Survey of Criminal Law Provisions Concerning Failure to Rescue" (1966) 14 Am. J. Comp. L. 630.

Difficult cases could arise. Which duties should be considered "general"? When should voluntary participation in an activity impute sufficient acceptance of attendant obligations? Thus, should the mere fact of putting a ship to sea import an assumption of the various statutory duties affecting ships masters, and a concomitant denial of relief? In the context of maritime salvage claims, the courts have said "no": above at note 72 . It might be argued, however, that because the penalties underlying the various maritime duties are not especially onerous, there is a particular need to encourage the provision of aid at sea with the availability of salvage awards.

To the contrary, it might be said that the benefits of a humane and interdependent society accrue to all citizens, and that the costs attendant upon a requirement to provide emergency assistance is the price to be paid for peace of mind and personal safety. Accordingly, it might be argued that rescuers are already compensated for their efforts and ought to be denied additional relief.

A seaman may be granted a salvage award although he acted in compliance with a statutorily imposed duty of general applicability, but he will generally be denied recovery for services rendered to his own vessel, for which he assumed a specific duty by becoming a crew member: supra note 110.

117 A rescuer's claim in such cases could also be resisted on the grounds that her right of recovery is governed by the terms of her contract, ibid. 
attended by some right of recovery. Thus, the courts should reject the claim of one who acted pursuant to her freely assumed duty as a parent or guardian. ${ }^{118}$

\section{Consent of Victim}

Given the need to discourage officiousness and protect freedom, a recipient of goods or services will generally ${ }^{119}$ not be liable in restitution if he did not enjoy an opportunity to reject the benefit. ${ }^{120}$ In the context of life rescue, the issue would seldom be problematic. ${ }^{121}$ Even if a victim had not cried out for help, consent to receive the services could typically be inferred from circumstance. Furthermore, given the general desirability of rescue, non-consent should not be presumed simply because a victim was incapable of considering the matter (e.g. because he was unconscious). If it were otherwise, intervention would often be discouraged when it was needed most. ${ }^{122}$

However, an interesting issue would arise if services were rendered over a victim's objections. ${ }^{123}$ When, if ever, would it be proper to impose upon a person the cost of services that he did not want? In Matheson v. Smiley, ${ }^{124}$ a physician was granted remuneration for treatment provided to a suicidal person. The court disregarded the fact

The law might recoil at a claim for recovery by a parent who rescued her son not simply because she voluntarily assumed the responsibility of doing so, but also because recognition of such a claim would be repugnant to common notions of morality.

An exception exists pursuant to the principle of incontrovertible benefit, of which rescue services would typically be an example: above at note 27 and below at note 128 and Section IV(E).

The requirement finds expression in the rule allowing recovery by an intervenor who fulfils another's duty, and in the doctrine of agency of necessity; relief is denied unless a claimant made an adequate attempt to communicate with the appropriate party: above at Sections III(E) and (F).

The issue of officiousness might not be entirely foreclosed even if a victim expressly consented to the provision of aid. Relief would properly be denied if, when services were rendered, a rescuer, but not a victim, knew that the arrival of a more appropriate intervenor was imminent.

While the creation of a contract for the immediate provision of services normally serves as very strong evidence of consent, the courts would almost certainly refuse enforcement of a bargain extracted from a person in peril. While there is surprisingly little authority on the point, the courts would likely rely upon the doctrines of unconscionability and, especially in Canada, inequality of bargaining power, to refuse enforcement. Nevertheless, just as a salvage award may be available even if a salvage agreement is set aside (The Medina (1876), 1 P.D. 272, aff'd. (1876), 2 P.D. 5), so too restitutionary relief might properly lie even if a contract for services was held to be unenforceable. Similarly, while a nonconsensual interference with another's body is generally actionable in tort, liability may not lie against a physician who provides emergency treatment to a person incapable of consenting because of unconsciousness or extreme illness: Marshall v. Curry, supra note 57; $F$. v. West Berkshire H.A., supra note 57.

In some situations, liability may lie for a failure to rescue a person who has intentionally placed himself in peril. A duty to rescue is commonly imposed on individuals who enjoy dominant status in a relationship of control or supervision. Thus, a jailer is required to take steps for the protection of a prisoner: (see e.g. Kirkham v. Chief Constable of Greater Manchester Police, [1989] 3 All E.R. 822, aff'd., [1990] 3 All E.R. 246 (C.A.)), and a hospital must safeguard its patients; see e.g. Lawson v. Wellesley (1975), 9 O.R. (2d) 657; aff'd., [1978] 1 S.C.R. 893, 76 D.L.R. (3d) 688; University Hospital v. Lepine, [1966] S.C.R. 561; Selfe v. Ilford \& District Hospital Management Committee, The Times, 26 November 1970. See generally, D. Braunstein, "Custodial Suicide Cases: An Analytical Approach to Determining Liability for Wrongful Death" (1982) 62 Boston U. L. Rev. 177. 59. 
that the doctor's services had been resisted, reasoning that it was "unreasonable to hold that [the victim] had any controlling mind at all in the circumstances." ${ }^{125}$ That was probably true given that he had just suffered a fatal, self-inflicted gunshot blast to the chest. It may also have been irrelevant.

Some commentators have argued that "the preservation of life is so important that the courts should encourage intervention in all circumstances." ${ }^{126}$ That view may be overstated. Admittedly, because the issue is largely one of ethics, it is impossible to prove or disprove certain positions. One opinion may be as logically sound as its competitor; the difference between the two may lie, intractably, in the way that their respective authors approach the universe. The view underlying the argument that follows accepts that insofar as people are recognized as having individual rights, they should have the right of selfdetermination. The primary value of a life is that it affords its holder the opportunity to pursue his chosen projects; if a person decides that his project is to die, the law should be wary of encouraging the frustration of that goal.

Recovery ought be denied if a rescuer acts in spite of clear evidence that a victim, being of sound mind and full age, had chosen to take steps to end his own life. ${ }^{127}$ Admittedly, it might be rare that a person in such a condition would decide to kill himself, and rarer still that such knowledge would be available to a rescuer. Furthermore, in cases of uncertainty, the policy of preserving life should prevail. Occasionally, however, circumstances will sufficiently militate against recovery. Consider a situation in which a person of clear mind is suffering from an incurable, exceedingly painful condition and decides to commit suicide. Steps are taken to that end, but at the last moment, a doctor intervenes and prevents death. ${ }^{128}$ The doctor's actions should not be encouraged

Supra notc 58 at 791.

Goff \& Jones, supra note 13 at 343 [emphasis added]. See also F.D. Rose, "Restitution for the Rescuer" (1989) 9 Oxford J. of Legal Stud. 167 at 187-188; Maddaugh \& McCamus, supra note 11 at 692-693, n. 64; Palmer, supra note 55 at 376.

Against the argument that a decision to commit suicide can never be the product of a clear mind, it can be noted that the law already recognizes a distinction between sane and insane suicides. Thus, there is a line of authority in tort law which imposes liability if a negligent act brought about an unstable mind which in turn led to a suicide, but which denies liability if the suicide, while following from a negligent act, was the product of a sane mind; Cotic v. Gray (1981), 124 D.L.R. (3d) 641, aff'd. 1 D.L.R. (4th) 187 (S.C.C.); Swami v. Lo (1980), 105 D.L.R. (3d) 451 (B.S.S.C.); Murdoch v. Br. Israel World Fed., [1942] N.Z.L.R. 600 (C.A.); cf. Pigney v. Pointers Tpt. Services Lid., [1957] 1 W.W.R. 1121. See also Robson v. Ashworth (1985), 33 C.C.L.T. 229, aff'd. 40 C.C.L.T. (Ont. C.A.).

In such circumstances, it would be difficult to argue that rescue services represent an incontrovertible benefit in the form of a "necessary expenditure": above at note 27 and below at Section IV(E). The victim clearly would not consider himself bound to incur the expenditure, and a reasonable man might deny that a benefit had been conferred: Birks, supra note 13 at 116-119. In Birk's terms, the victim's actions would evince a "subjective devaluation" of the services rendered.

Speaking of the scope of incontrovertible benefits, McLachlin J. recently held that "it would be wrong to make the defendant pay...[if] he or she...preferred to decline the benefit": Peel (Reg. Mun.) v. Canada, Peel (Reg. Mun.) v. Ontario, supra note 27 at 24. 
through the availability of restitutionary relief. ${ }^{129}$

Returning to Matheson v. Smiley, it is suggested that the court erred in dismissing the defence of non-consent on the bare grounds that the victim was incapable of clear thought when the doctor reached him. While that condition may have been a continuation of a preexisting state, the court should have at least considered the possibility that the victim had previously decided to commit suicide while being of full age and sound mind. ${ }^{130}$ If that was the case, and if the doctor had been reliably informed on that fact, then relief should have been denied. ${ }^{131}$

\section{APPROPRIATE INTENTION IN INTERVENING}

A rescuer's intention would be relevant in two respects: relief would properly be denied if a rescuer did not act substantially in the interests of the victim, or if he acted with the intention of conferring a gratuitous benefit.

Restitution is generally denied to those who confer benefits upon others while acting entirely out of self-interest. ${ }^{132}$ If the law were to hold otherwise, there could be a flood of litigation, as many selfish acts incidentally benefit others. ${ }^{133}$ Moreover, in such cases, the availability of relief is obviously unnecessary for the purpose of eliciting action. Finally, as between two innocents, the fact that a plaintiff chose to incur a cost solely for his own benefit constitutes a very good reason for refusing to shift that cost onto a

Nor should the doctor's actions be condoned. In Malette v. Shulman (1987), 47 D.L.R. (4th) 18, aff'd. 67 D.L.R. (4th) 321, a doctor performed an emergency blood transfusion on a woman despite knowledge of a card found on her person vigorously objecting to such a procedure because of her religious beliefs as a Jehovah's Witness. While the decision is difficult on its facts, the court relied on a sound principle in awarding damages in tort against the doctor. In the words of Cardozo J., "Every human being of adult years and sound mind has a right to determine what shall be done with his own body": Schloendorff v. Society of New York Hospital, 105 N.E. 92 at 93 . Cf. Re T, [1992] 4 All E.R. 649 (C.A.).

In the context of restitutionary claims, Jones has argued that a person who attempts suicide "should be regarded as incompetent as [a] mentally disordered person" whose non-consent should be ignored. However, Jones also states that the wishes of a Christian scientist (who, like a Jehovah's Witness, may refuse medical treatment on religious grounds) ought to be respected; supra note 5 at 161 . Cannot a decision to die be as sound and as informed as a decision to accept religious tenets that imperil one's life? Of what determinative legal relevance is the supposition of God's wishes? It would be absurd to deny relief if a rescuer acted at a time when a victim of full age and sound mind was seized of a decision to kill himself, but to allow recovery if a rescuer waited until a victim had done himself sufficient harm as to lose the capacity for rational thought. The case report does not reveal evidence that either of those conditions existed; indeed, the judgment was probably correct in result. The objection taken here is to the court's reasoning. Somes v. British Empire Shipping Co. (1860), H.L.C. 338; Burns Philp \& Co. Ltd. v. Gillespie Bros. Pty Lid. (1947), 74 C.L.R. 148; Ulmer v. Farnsworth, 15 A. 65 (Me. S.J.C. 1888). The absurdity of allowing relief was noted by the Earl of Halsbury L.C. in Ruabon Steamship Company v. The London Assurance, [1900] A.C. 6 at 12: "So that if a man were to cut down a wood which obscured his neighbour's prospect and gave him a better view, he ought upon this principle to be compelled to contribute to cutting down the wood." See also Peel (Reg. Mun.) v. Canada, Peel (Reg. Mun.) v. Ontario, supra note 27 at 797. 
defendant. In the present context, then, a rescuer should not be permitted recovery under the proposed rule if he acted with the sole aim of benefitting himself. ${ }^{134}$

A more difficult issue would arise if a rescuer acted with the knowledge that in saving himself, he would also save another person. ${ }^{135}$ Consider a case in which either of two parties is capable of incurring a cost that will remove a peril that threatens them both. Only one need act, but if neither do, both will die. Admittedly, recovery would not be needed for behaviourial purposes. On the other hand, it would seem unfair to allow the incidental beneficiary to parasitically enjoy the fruits of the other's expenditure. ${ }^{136}$ Furthermore, the argument that the imposition of liability would infringe upon the beneficiary's freedom to control his own purse strings would be attenuated in the circumstances; had the cost in question not been borne by the rescuer, the incidental beneficiary surely would have incurred it. Consequently, it follows that contribution should be ordered. ${ }^{137}$

Clearly, relief would properly be denied if a rescuer acted with a gratuitous intention. ${ }^{138}$ The difficult issue is the evidentiary one: upon whom should the onus of proof lie, and what should it require? The law regarding the supply of necessities to the incapacitated suggests by analogy that a rescuer could be required to positively establish that she acted with the intention of creating a debt. ${ }^{139}$ Such a burden could seldom be discharged. Often, a rescuer would give little consideration to legal matters before acting; she would simply perceive a need and meet it. At the time of intervention, she would not consciously intend to act gratuitously nor to recover from the victim.

For example, relief should be denied if an accident victim drove himself to the hospital, unaware that another victim of the same calamity had inadvertently staggered into the back of his vehicle. Of course, the element of self-interest need not be related to self-rescue. Thus, relief should also be denied if the operator of a power boat inadvertently washed a drowning man to safety with the wake of the craft.

While restitutionary relief was traditionally denied to individuals who acted with mixed motive, there is recent dicta to the contrary: The Winson, supra note 90 at 966, Lord Simon; Hink v. Lhenen (1974), 52 D.L.R. (3d) 301; Goff \& Jones, supra note 13 at 41.

In the context of maritime law, the existence of professional salvors is testimony to the fact that services are frequently motivated partially by the prospect of personal gain; the law actively appeals to the economic interests of salvors through the promise of rewards. As will be discussed below, the availability of relief for the life rescuer would also be properly premised upon an element of selfinterest; relief should be denied if a rescuer intended to confer a gratuitous benefit.

Admittedly, it is a fine line between the present hypothetical and one in which a rescuer unwittingly assists an incidental beneficiary: above at note 134. Arguably, the latter would be a proper case for restitutionary relief on the grounds of wrongdoing if the incidental beneficiary secretly and cynically took advantage of the rescuer's actions: Birks, supra note 13 at 326-333; Goff \& Jones, supra note 13 at 612-613; Burrows, supra note 25 at c. 14; Maddaugh \& McCamus, supra note 11 at c. 23. That possibility finds analogous support in the principle of general average contribution in maritime law: see generally Sir J. Donaldson, Sir Christopher Staughton, D.J. Wilson, eds., Lowndes \& Rudolf's Law of General Average and the York-Antwerp Rules, 10th ed. (London: Stevens \& Sons, 1975).

Under the Canadian formulation of the unjust enrichment principle, restitution is possible only if there is an "absence of any juristic reason - such as contract or disposition of law - for the enrichment": Rathwell v. Rathwell, supra note 12 at 455 . The conferral of a benefit in the intention of making a gift is a juristic reason for an enrichment: Maddaugh \& McCamus, supra note 11 at 45-46. 
The onus should be on a defendant to prove that services were rendered gratuitously. ${ }^{140} \mathrm{~A}$ rescuer should be presumed to act with an intention of being reimbursed, ${ }^{141}$ and if she is a professional, of also being remunerated. ${ }^{142}$ Conceivably, both classes of rescuers could benefit from the more generous view. However, while presumptions obviate the need for proof of fact, they should not be entirely divorced from reality. It would be plausible to presume that a professional intended to charge for her services, because that is what she normally does. ${ }^{143}$ The same could not be said with respect to non-professionals. ${ }^{144}$

\section{REASONABLENESS OF ACTIONS}

Earlier, it was said that a rescuer should be denied relief if it was unreasonable for him to intervene. He should similarly be refused recovery if the acts he performed were themselves unreasonable. ${ }^{145}$ For example, it may be reasonable for a person to intervene if a friend's sleeve becomes entangled in a running motor, but it may be unreasonable to free the victim by hacking his arm off at the shoulder.

A rescuer's unreasonable actions may provide a victim with a sword, as well as a shield; in addition to resisting a claim for relief, a victim could pursue a claim for compensation in tort. ${ }^{146}$ In either case, however, the law should be slow to find fault in the actions of a rescuer; the appropriate standard of care should be that of reasonableness

Indeed, that seems to have been the approach taken in Matheson v. Smiley, in which remuneration was granted: supra note 58. While citing the decision in Re Rhodes (supra note 65), the court made no mention of evidence that the physician had acted with the intention of charging for his services, but spoke of the fee that the plaintiff would "reasonably expect to receive." See also Maddaugh \& McCamus, supra note 11 at 695; Goff \& Jones, supra note 13 at 340-341, 343.

It has been suggested that if asked at the time of conferring a benefit, most intervenors would not say that they intended to be remunerated, but many would indicate an intention to be reimbursed: J.D. McCamus, "Necessitous Intervention: The Altruistic Intermeddler and the Law of Restitution" (1979) 11 Oltawa L. Rev. 297 at 313.

Necessitous intervenors often benefit from presumptions. An agent of necessity is entitled to recover her expenses unless it is proven that she acted with a gratuitous intent: Goff \& Jones, supra note 13 at 346 . And while a maritime salvor will be denied a reward if he acts gratuitously, he generally need not adduce evidence that he acted with the intention of receiving a reward: Kennedy's, supra note 35 at 25-26. The same is true under the Roman law concept of negotionum gestio: above at note 53. While a professional in the midst of a crisis may not consciously direct her mind to the matter of remuneration, it is reasonable to believe that if she did consider the issue, she would form the opinion that she should be paid the value of her services.

Of course, because the law may foster expectations, the situation could become otherwise if all rescuers were presumed to act with an intention of being remunerated.

The requirement of reasonableness of actions is a common limiting factor. Thus, while restitution is generally available to one who unofficiously fulfils another's obligation to bury a corpse, full compensation is denied if the intervenor unreasonably provides a pauper with a funeral fit for a king. Similarly, a maritime salvor who performs unreasonable acts may, depending upon the severity of his misconduct, be denied his costs, receive a reduced award or have his award forfeited altogether: "Maritime", supra note 35.

146 Horsley v. McLaren, [1970] 2 O.R. 487 at 495, 500; Zelenko v. Gimbel Bros., 287 N.Y.S. 134 (1935), aff'd. 287 N.Y.S. 136 (1936); cf. East Suffolk Rivers Catchment Bd. v. Kent, [1940] 4 All E.R. 527 (H.L.). In the context of maritime salvage, see e.g. The Tojo Maru, [1972] A.C. 242. 
in the circumstances, not perfection. ${ }^{147}$ The tort law doctrine of "sudden peril" holds that a person confronted with an emergency is not expected to react with the same level of prudence and ability that would be demanded under less stressful conditions. ${ }^{148}$ Though clearly inappropriate when viewed in hindsight, actions may be considered reasonable when viewed in the context of an exigency.

\section{E. SUCCESS}

A rescuer may justifiably intervene in an emergency with the requisite intention and provide reasonable services, but nevertheless fail to save a victim from harm. ${ }^{149}$ Should that lack of success be fatal to his claim..$^{150}$ On policy grounds, a requirement of success would undermine the behaviourial impact of a rule allowing recovery. Unless confident of success, a bystander might be unwilling to undertake a costly rescue effort, ${ }^{151}$ and a victim could be thereby deprived of a source of potential salvation. ${ }^{152}$ Moreover, it would be harsh to cast the burden of an unsuccessful effort on a would-be rescuer who had acted reasonably in a victim's best interests. ${ }^{153}$

A similar standard applies to necessitous intervenors under the Roman law doctrine of negotiorum gestio: Kolbin and Sons v. Kinnrar and United Shipping Co., [1931] S.C. 128 at 129, Lord Atkin; cf. Bannatine's Trustee v. Cunninghame (1872), 10 M. 319 at 325-326. C.P. Ltd. v. Gill, [1973] S.C.R. 654; Jones v. Boyce (1816), 171 E.R. 540; Klar, supra note 2 at $220-$ 222; R. Dias \& B. Markesinis, Tort Law (Oxford: Clarendon Press, 1989) at 98-99. While maritime salvage awards are premised upon success, that requirement is largely attributable to factors unique to the maritime context: above at note 73 .

Success is not a pre-requisite under the doctrines of agency of necessity (above at Section llI(F)) or negotiorum gestio. Dawson, supra note 32 at 1115 ; Walker, supra note 53 at 514. Academic opinion is divided: Goff \& Jones, supra note 13 at 343; Maddaugh \& McCamus, supra note 11 at 693 (no requirement of success); Burrows, supra note 25 at 247 (requirement of success). A bystander's lack of confidence would not necessarily be indicative of an act that would be noncompensable on the grounds of unreasonableness. A bystander might be particularly risk averse. So too might his initial assessment be erroneous given the frenzied circumstances of a emergency. Finally, it may be reasonable to perform an act that is not certain to be successful. Burrows argues that a requirement of success would be desirable as it would discourage rescuers from making half-hearted efforts: supra note 25 at 247 . More likely, it would discourage potential rescuers from making any efforts at all. Because most people feel internally motivated to provide succour, a bystander is apt to provide a reasonably full effort once he has become involved in an emergency. But the fear of incurring financial losses may inhibit him from acting initially: "Psychological", supra note 42 at 688-689.

While the highest praise may be reserved for those who succeed in averting a threatened harm, a rescuer stands to be commended even if he fails in his goal. As Dawson noted (supra note 32 at 1115):

[W]hatever merit his claim may have will be primarily due to his willingness to incur inconvenience or danger in responding to another's need, thercby serving a social interest in the conversation of human life. The merit is not reduced if his effort fails. 
The law of restitution is based on the reversal of unjust enrichments, so that a failure to confer a benefit generally precludes recovery. ${ }^{154}$ Consequently, however, much public policy may favour liability, the availability of relief would be more easily and readily accepted if a benefit could be shown to have moved from a rescuer to a victim. ${ }^{\text {iss }}$

It might be said that even a failed rescue attempt confers a benefit by increasing a victim's likelihood of escaping injury. But in some cases, that simply would not be true; an effort would have been doomed from the outset. ${ }^{156}$ Furthermore, courts are seldom willing to impose liability on the basis of probabilistic notions of harm and wellbeing. ${ }^{157}$

The difficulty of finding a benefit might also be avoided by analyzing a situation in terms of "unjust sacrifice" rather than "unjust enrichment." 158 Whereas the latter approach would look to both a rescuer's loss and a victim's gain, the former would focus exclusively on the intervenor's position. However, that analysis is unlikely to find favour in the courts. ${ }^{159}$ Because unjust sacrifice indicates why a plaintiff should receive relief, but does not suggest any reason why a defendant should be held liable, courts generally speak in terms of unjust enrichment.

A third possibility would be to deem a victim to have received a benefit even if none was actually conferred. ${ }^{160}$ Such sleight of hand might make the availability of relief more palatable to some observers, but it would be preferable to address the issue more honestly. The law tends to be drawn into disrepute when it deems, rather than establishes, facts.

The most convincing approach would be to recognize an incontrovertible benefit in the form of a necessary expenditure. ${ }^{161}$ In Birks terminology, no reasonable man would

It has been said that relief might properly lie even in the absence of a benefit upon which recovery could be ordered as a means of reversing an unjust enrichment. In such situations, liability would be based simply on the desirability of encouraging intervention: Goff \& Jones, supra note 13 at 22 ; Burrows, supra note 25 at 247.

If services were availing, then a victim could be considered to have enjoyed an "incontrovertible benefit" insofar as he was saved an inevitable expense: above at note 27 .

1.56 That may be so even though intervention and the services rendered were reasonable; a rescuer could fail for reasons which existed all along, but which could not be perceived at the time of action. Moreover, it may be reasonable to perform an act which is not certain of success. 609 (S.C.C.); cf. Janiak v. Ippolito (1985), 16 D.L.R. (4th) 1 (S.C.C.). See generally J.G. Fleming, "Probabilistic Causation in Tort Law" (1989) 68 Can. Bar. Rev. 661. 2d ed. (London: Law Book Co., 1989) at 9-10, c. 7; J. Beatson, The Use and Abuse of Unjust Enrichment (Oxford: Clarendon Press, 1991) at 21-44; S. Hedley, "Unjust Enrichment as a Basis of Restitution - An Overworked Concept" (1985) 5 Legal Studies 56 at 60-63. Batis, [1990] 1 Lloyd's Rep. 345 at 353. 
deny that the victim had been enriched by the receipt of a rescue attempt. ${ }^{162} \mathrm{~A}$ victim would have considered himself bound to incur the cost of a rescue, and would have sought out such a service if circumstance had not prevented him from doing so. ${ }^{163}$ Furthermore, he almost surely would have done so, even if he had known that a service might be unavailing. ${ }^{164}$

Finally, the argument that relief should be available despite a lack of success finds support in precedent. The Road Traffic Act 1988 (U.K.) allows physicians to recover for services arising from motor accidents even if treatment is unavailing. ${ }^{165}$ Similarly, remuneration was granted in the leading case of Matheson v. Smiley, ${ }^{166}$ although the victim died. Indeed, it was apparently clear to the rescuer from the start that his endeavours would likely be unsuccessful. As Robson J.A. noted however: ${ }^{167}$

I think it is not within reason that even in such circumstances as are revealed here a person in such a plight should simply be allowed to die without an effort being made.... I hardly think it an answer to say... there was no hope. In such circumstances no one gives up while a spark remains.

\section{REMEDIES}

Accepting that relief should be available to rescuers, there remains the difficult matter of quantifying awards. ${ }^{168}$ The appropriate measure of recovery could involve one or more of the following possibilities: (i) reward, (ii) reimbursement of expenses, (iii) remuneration for services, (iv) compensation for losses and injuries.

Supra note 13 at 116-119. See also Maddaugh \& McCamus, supra note 11 at 693 . Cf. above at Section $\operatorname{IV}(C)(2)$ (suicidal victims).

Burrows argues to the contrary, noting that "a reasonable man could say that he would only have been willing to pay for a result not an attempt": supra note 25 at 247 . Certainly, a churlish man might adopt such a position after the fact, but at the time of crisis, it is doubtful that any reasonable man would discourage potential rescuers by threatening "no cure - no pay."

Moreover, as Birks notes, "when one says that a given expenditure was factually necessary or inevitable for the defendant, one excludes unrealistic or fanciful possibilities of his doing without it.": supra note 13 at 120.

However, relief would properly be denied if a rescue attempt failed because it was unreasonable: above at Section IV(D). A victim would not have sought out such a service. Road Traffic Act 1988, (U.K.), 1988, s. 158(1)(a): above at Section III(B).

106 Supra note 58. Similarly, in the American case of Cotnam v. Wisdom, supra note 55, a physician was awarded remuneration for services rendered even though the recipient of the treatment died without regaining consciousness.

Matheson v. Smiley, ibid. at 789. Recovery should be denied if intervention or procedures employed are unreasonable in the circumstances: above at Section IV(D). Relief should not be granted in the exceptional case in which a rescuer acted despite being absolutely certain that a victim could not be spared by any means.

Arguably, the quoted passage could be read to suggest otherwise insofar as it speaks of the provision of aid even when there is "no hope." It is suggested, however, that emphasis should be placed on the next sentence, in which Robson J.A. spoke of a "spark" remaining. Presumably, he was referring to a spark of hope that the victim could be saved, not a spark of life which a rescuer knows is unavoidably about to be extinguished.

10* It will generally be assumed that all of the conditions for recovery discussed in the previous section have been met. For example, references to expenses should be taken to mean reasonable expenses. 


\section{A. REWARD}

Taking the simplest matter first, it can be said that there is little to recommend the availability of rewards - i.e. awards that exceed in value that which would be appropriate as reimbursement or remuneration. ${ }^{169}$ Such relief would be most difficult to justify on the grounds of reversing unjust enrichments. ${ }^{170}$ Additionally, more than any other measure of relief, rewards would impinge upon the freedom of victims to control their own resources.

Where little or no property has been rescued, maritime life salvage rewards may be paid from public coffers. ${ }^{171}$ While a detailed consideration of the possibility lies outside the scope of the present inquiry, it is conceivable that a similar scheme could be adopted with respect to life rescue on land. ${ }^{172}$ One benefit of such an approach is that it would spread the costs associated with intervention over the entire community, as would be the case if assistance was provided not by a private citizen, but rather by a servant of the state. Furthermore, the availability of rewards might have a significant behaviourial effect; the promise of generous relief might elicit intervention from otherwise inactive bystanders. However, the allure of rewards might prove too great and moral hazards could arise; rogues would be tempted to intentionally create the need for services which they could satisfy for personal gain.

\section{B. REIMBURSEMENT}

The form of relief most likely to be made available to rescuers is reimbursement of expenses. ${ }^{173}$ Difficulties arise, however, in defining and confining the meaning of

While it is true that maritime salvors are granted rewards, such relief is supported by special considerations that are inapplicable with respect to life rescue on land: above at Section III(D).

The amount of a reward could exceed the value of the rescuer's loss or the victim's gain. For that reason, it would be inaccurate to speak of rewards as constituting restitution. "[N]othing counts as restitution unless the measure of the defendant's liability is the enrichment received by him the plaintiff's expense": Birks, supra note 13 at 307. See also Burrows, supra note 25 at 248-249; Mason v. LeBlaireau, 6 U.S. 238 at 266 (U.S.S.C., 1804).

Above at Section III(D).

State funded awards could also be paid as reimbursement, remuneration or loss compensation. In Quebec, a commission established under the Worker's Compensation Act is authorized to compensate rescuers for injuries sustained in the course of intervention. Furthermore, the Minister of Justice may recommend to the Government that a rescuer be granted a reward of up to $\$ 5000$, or a decoration or distinction, even if he does not suffer a loss as a result of his efforts: An Act to Promote Good Citizenship, R.S.Q. 1977, c. C-20, ss. 15-17. State awards are also available in Austria: Dawson, supra note 32 at 1121.

Maddaugh \& McCamus, supra note 11 at 693; Goff \& Jones, supra note 13 at 341, 343; Jones, supra note 5 at 162-165.

Such relief is available to other types of necessitous intervenors, such as those who supply necessaries to the incapacitated, those who fulfil the obligations of others by burying corpses, and those who act as agents of necessity. Furthermore, the Road Traffic Act 1988, supra note 165, allows legally qualified medical practitioners to recover, inter alia, specified charges, in the nature of expenses, associated with travel to and from the scene of accidents. Finally, claimants under the Roman law concept of negotiorum gestio are generally restricted to reimbursement of expenses: see e.g. Walker, supra note 53 at 513; cf. M.S. Amos \& F.P. Walton, Introduction to French Law, 3d 
"reimbursement". As will be seen shortly, it is possible to expand the scope of the term to include costs for which a victim arguably should not be liable. Furthermore, the availability of reimbursement for expenses may logically suggest recognition of other forms of relief.

At its simplest, reimbursement would allow a rescuer to recover the value of sums expended and materials consumed in the course of intervention for the direct purpose of providing assistance. Thus, if an intervenor hired a doctor to provide medical care to a victim, he would receive the amount paid to the physician. Similarly, if he used gasoline driving a victim to hospital, or ruined a shirt by using it as a bandage, he would receive the value of those goods.

\section{REMUNERATION}

The question of whether or not rescuers should receive remuneration for their services is best addressed in two parts: first, as regards "professionals", and second, as regards others. The term "professional" refers here to one who habitually receives remuneration for providing the type of service rendered, but who claims for acts performed in the absence of any contract. ${ }^{174}$ An example is an off-duty physician who happens upon an emergency and provides assistance. ${ }^{175}$

A strong case can be made for the availability of remuneration for professionals. First, a victim should not enjoy a windfall and a physician should not be denied his usual fee simply because of the fortuitous circumstances of a peril. ${ }^{176}$ Under normal conditions, the provision of medical treatment would clearly entail a right to remuneration; indeed, in stopping to help a victim, a physician may forego an opportunity to render services in the ordinary course of his paying practice. Second, insofar as the availability of relief would have a behaviourial impact, it would be most desirable to encourage intervention from the people best equipped to provide effective assistance. Third, remuneration has already been granted to professionals in a small number of cases. ${ }^{17}$ Finally, the administrative costs associated with the quantification of such awards would generally be

ed. (Oxford: Clarendon Press, 1967) at 194.

As previously explained, restitutionary relief should be denied to one who acts pursuant to a contractual obligation; his remedy properly lies under the terms of his bargain: above at note 110 . The issue will seldom arise in practice. Physicians are typically paid by the state, and therefore have no need to pursue claims against the people to whom they render services: above at note 56 . The discussion that follows is nevertheless important in that it informs a consideration of the possibility of remuneration for other types of professionals, and for non-professionals.

Against a victim's contention that the law should not impinge upon his freedom to choose his salvor stands the fact that he will have enjoyed a benefit from a physician's services, and if he had been capable of doing so, he would have agreed to purchase those services. 
minimal as reference could easily be made to the amount normally charged for the type of service provided. ${ }^{178}$

A more difficult question is whether or not the non-professional should ever be granted remuneration. ${ }^{179}$ Certainly, a victim generally should not be liable to a lay person in the same quantum that he should be liable to a professional; ${ }^{180}$ the latter will typically render services more competently and to greater effect. Occasionally, however, a nonprofessional will perform exactly the same procedure as a professional, with exactly the same result. Furthermore, while a victim may prefer to receive services from a professional, none may be present. If this is the case, it would be good policy to encourage intervention from whoever is available. Finally, incongruities could arise if lay persons were permitted reimbursement, but not remuneration. A rescuer would be able to recover the expense of hiring a physician to perform a particular procedure, but would be denied remuneration if he performed the procedure himself.

On the other hand, a victim should not have to pay for a benefit conferred with a gratuitous intention. As previously noted, while it would be plausible to presume that a non-professional intended to be reimbursed, the same generally could not be said of remuneration. ${ }^{181}$ Furthermore, even if a lay person could positively prove an intention to collect remuneration, practical difficulties would weigh against the availability of such relief. It is not clear how an award to a non-professional would be quantified. Because there is no market for his services to which reference could be made, the process required to arrive at a proper valuation of the time and effort expended could be protracted and costly. Indeed, the administrative cost of computation might often exceed the value of a claim. ${ }^{182}$ And while notions of economic efficiency may not warrant the role that some legal theorists would assign to them, the law should be wary of introducing rules in which social and economic costs could outweigh benefits. ${ }^{183}$

A minor controversy has arisen as to whether or not a court should take into account a defendant's ability to pay, where such a consideration customarily affects the size of a doctor's bill. While the court in Cotnam v. Wisdom, supra note 55 answered in the negative, the generally preferred view is to the contrary: Matheson v. Smiley, ibid.; Re Agnew's Will, 132 Misc. 466, 230 N.Y.S. 519 (1928). The weight of academic opinion is in the negative: Maddaugh \& McCamus, supra note 11 at 693; Goff \& Jones, supra note 13 at 343.

Jones has suggested that it would "make no sense" to remunerate a non-professional: supra note 5 at 153 . While it would admittedly be unusual to do so, there is no reason why it would not make sense. Remuneration would simply compensate a rescuer for the time and effort expended in rendering assistance. A lay person is just as capable as a professional of expending time and effort. By way of analogy, it can be noted that the value of a maritime salvage award depends in large part on whether or not a salvor is an amateur or a professional, and if he is a professional, the extent to which he focuses his energies on the provision of salvage services as opposed to other tasks, such as towage; The Queen Elizabeth (1949), 82 L1.L.R. 803. Above at Section IV(C).

The value of a non-professional's services might generally be low because the actions performed would not have been particularly skilful or difficult. The same would often be true of a professional's services, but in that case, the cost of valuation would be lower, as reference could be made to the usual fee charged for such services

In the absence of empirical evidence, it cannot be known whether the costs attendant upon a rule granting remuneration to non-professional rescuers would exceed the benefits derived. Nevertheless, the possibility of an overall negative effect is significant enough to warrant caution. 


\section{COMPENSATION FOR LOSS AND INJURY}

Finally, it must be asked whether a rescuer should be entitled to recover from an innocent victim ${ }^{184}$ not only for reimbursement for his expenses, but also compensation for his losses and injuries. The issue has been illustrated by Professor Jones. ${ }^{185}$ A man dives into a lake to save a drowning woman. In the course of intervention, he binds the wounds of the victim with his necktie. Unfortunately, his suit is ruined by the water and his gold watch chain irretrievably sinks to the bottom of the lake. In Jones' view, the use of the necktie represents an expense for which the rescuer should receive reimbursement. The suit and the watch chain, in contrast, were not expended, but rather lost, and therefore should not be the subject of relief. While he does not expressly say so, the distinction for Jones appears to turn on whether or not an item was directly involved in the provision of assistance, such that the effort could not have been performed without it.

If it is conceded that the rescuer should be permitted recovery for the value of his necktie, it is only a narrow view of the term "expense" that denies relief with respect to his suit and watch chain. Yet it would not be unreasonable to speak of the suit and watch chain as having been expended in the rescue effort. ${ }^{186}$ Conceivably, it may have been necessary for those items, like the necktie, to be ruined or lost if the woman was to be saved; the peril may not have afforded the man time to disrobe before entering the water. Similarly, if the rescuer had been injured in the course of intervention, it could be argued that the woman would not have been saved but for the man's personal sacrifice.

The availability of recovery of all expenses and losses is favoured on behaviourial grounds. Bystanders might be more willing to intervene in an emergency if they were confident that they would not suffer as a result. ${ }^{187}$ Moreover, such relief might also be justified as an instance of reversing an unjust enrichment. The value of the victim's benefit could be measured by reference to the total cost of intervention, including not only a rescuer's expenses (narrowly defined), but his losses and injuries as well. ${ }^{188}$

Difficulties arise, however, when the matter is viewed from the perspective of the victim. To permit recovery of all losses and injuries could entail the imposition of a crushing financial burden on one who became imperilled without fault. A vivid illustration

A rescuer may recover compensation in tort law for losses or injuries sustained during intervention from a person who negligently creates a peril: above at note 3 . In the absence of fault, compensation could also be paid to a rescuer from public funds: supra at note 172 .

185 Supra note 5 at 164-165.

It is largely irrelevant that the term "expense" may generally be used in Jones' narrow sense. The present discussion questions, at a higher level of abstraction, the need in practice and in theory for limiting a rescuer's right of recovery in a particular way.

For a full discussion, see "Psychological", supra note 42 at 688-689; "Economic", supra note 37 at 260-263; cf. "Salvors", supra note 35 at 111-112.

While restitutionary relief is generally confined to the value common to a plaintiff's loss and a defendant's gain, it is often unclear how the latter should be quantified when a service, rather than money, is provided. Among the possibilities are the plaintiff's costs, the market value of the benefit, or the value placed on a benefit by a defendant; Maddaugh \& McCamus, supra note 11 at 72 . See also Goff \& Jones, supra note 13 at 26-29. 
is provided by an unfortunate decision of the German Reichsgericht. ${ }^{189}$ Frau B was a passenger in a car which non-negligently slid off a road and into a river. She managed to escape from the vehicle, but remained in great peril because she could not swim. $G$ responded to Frau B's cries for help ${ }^{190}$ by diving into the river and holding her head above water until other rescuers pulled her ashore. Sadly, G was killed in the course of performing the life saving service. An action was brought against Frau B by the widow and minor children of $G$ for loss of support; the widow sought a life annuity and the children asked for annuities to the age of majority.

The claims were allowed. Under the German concept of negotiorum gestio, ${ }^{191}$ rescuers were permitted recovery of "outlays." While that term had previously been confined to money, materials and time consumed in the provision of assistance, its scope was enlarged in the present case to include losses and injuries suffered in the course of emergency intervention. The remarkable result was that Frau B became obligated to financially support G's widow and children. Certainly, Frau B enjoyed a great benefit as a result of G's efforts; equally, the claimants suffered a great loss upon his death. In a perfect world, Frau B would have voluntarily provided support to the grieving widow and children. Unfortunately, there is nothing to suggest that she was, in fact, financially capable of bearing such a onerous burden. In the absence of fault, it seems very harsh to impose liability on one who "did no more than respond to the deep human impulse for survival and call out for help." 192

Clearly, then, policy considerations demand a limited scope of liability. The rule advocated by Jones is useful insofar as it would often restrict a rescuer's measure of recovery to an amount which would not cause financial hardship for a victim. However, that would not always hold true; occasionally, the value of a rescuer's "expenses" may far exceed the value of his "losses" (to use Jones' terminology). ${ }^{193}$ Jones' view might also be defended on the grounds that it respects the general principle that liability should not be imposed without fault. ${ }^{194}$ And while there is certainly validity in that point, it is also true that the distinction between expenses, for which he argues restitution should lie, and losses, for which he argues recovery should be denied, is rather arbitrary and uncertain. How directly, and to what extent, must a chattel be used in a rescue effort before it can become the subject of relief?

Bl. v. G. Reichsgericht (VI. Zivilsenat) May 7, 1941, 167 R.G.Z. 83. For a thorough examination of the case, see Dawson, supra note 32 at 1108-1112, 1121-1124.

The court held that Frau B's cries for help were of no legal significance, and in particular did not constitute an offer of contract.

Above at note 53.

192 Dawson, supra note 32 at 1115.

193 Consider a situation in which a person is touring a guest through his well-appointed home. The guest's clothes burst into flames when he non-negligently brushes against a candle. The only available means of rescue entails smothering the fire with a priceless tapestry. In the course of the effort, the rescuer suffers minor burns to his hands, and his inexpensive jacket is ruined. Applying Jones' rule, the rescuer could recover the value of the expensive tapestry, but would be without relief with respect to his physical injury and the loss of his jacket.

194 Similarly, the decision in Frau B's case has been criticized on the grounds that German law generally does not impose liability without fault: Dawson, supra note 32 at 1110, 1122. 


\section{CONCLUSION}

Restitutionary relief should be available to life rescuers. Analyzed in terms of the Canadian principle of unjust enrichment, it can be said that a victim receives an enrichment and a rescuer suffers a corresponding ${ }^{195}$ deprivation when there is not juristic reason for the enrichment. Policy considerations and precedent further favour the recognition of a right of recovery.

A rescuer's right of recovery should, however, be carefully limited. Relief would properly be denied if a rescuer:

(i) did not act in response to an emergency;

(ii) acted officiously in that he was not an appropriate person to intervene;

(iii) acted pursuant to a specific obligation;

(iv) acted in disregard of the fact that a victim of full age and sound mind refused assistance;

(v) intended to gratuitously confer a benefit;

(vi) did not act in the victim's best interests; or

(vii) performed actions that were unreasonable in the circumstances.

Furthermore, a rescuer's measure of relief generally should be restricted to reimbursement of his expenses, though a professional should also be entitled to remuneration for his services. Policy considerations militate against the availability of privately financed rewards, and against compensation for losses and injuries. 